\title{
Effect of pH Value on Synthesis and Properties of Zinc Cobalt Ferrite Nano Powders Prepared via Co- Precipitation Method
}

\section{Behrooz Shahbahrami}

Babol Noshirvani University of Technology

Sayed Mahmood Rabiee ( $\square$ rabiee@nit.ac.ir)

Babol Noshirvani University of Technology https://orcid.org/0000-0003-1628-7117

\section{Reza Shidpoor}

Babol Noshirvani University of Technology

\section{Research Article}

Keywords: Cobalt ferrite, Coprecipitation, Cation distribution, Magnetic properties

Posted Date: May 15th, 2020

DOI: https://doi.org/10.21203/rs.3.rs-28190/v1

License: (c) (i) This work is licensed under a Creative Commons Attribution 4.0 International License.

Read Full License 


\title{
Effect of pH Value on Synthesis and Properties of Zinc Cobalt Ferrite Nano Powders Prepared via Co-Precipitation Method
}

\author{
B. Shahbahrami, S. M. Rabiee*, R. Shidpoor \\ Department of Materials Engineering, Babol Noshirvani University of Technology, Babol, Iran \\ *Corresponding Author Email: rabiee@nit.ac.ir
}

\begin{abstract}
The effect of $\mathrm{pH}$ value on the synthesis of zinc cobalt ferrite nano powder via co-precipitation method was investigated. Zinc cobalt ferrite $\left(\mathrm{Co}_{0.6} \mathrm{Zn}_{0.4} \mathrm{Fe}_{2} \mathrm{O}_{4}\right)$ precipitated using a solution of nitrate raw materials under different $\mathrm{pHs}\left(\mathrm{pH}=8,10,11,12\right.$ and 14) and calcined at $750{ }^{\circ} \mathrm{C}$ for 2 hours. The obtained nano-powders were characterized by X-ray diffraction (XRD), Williamson-Hall relations and Extrapolate functions, field emission scanning electron microscopy (FESEM) and vibrating sample magnetometer (VSM) measurements.

The amount of $\mathrm{pH}$ had a significant effect on the structural and magnetic properties of the synthesized powders. At pHs 8 and 10, a tensile strain and above that a compressive strain was created in the system. By changing the tensile strain to compression the crystallite diameter increased, so that the crystallite diameter increased from $19.3 \mathrm{~nm}$ at $\mathrm{pH} 8$ to $47.8 \mathrm{~nm}$ for $\mathrm{pH}=11$. The $\mathrm{H}_{\mathrm{C}}$ of the all samples was in the range of 140-150 Oe. The saturation magnetization, anisotropy and Bohr magneton constants were $100.38 \mathrm{emu} / \mathrm{gr}, 15357.70 \mathrm{erg} / \mathrm{Oe}$ and 4.27 , respectively for the synthesized sample at $\mathrm{pH}=11$, which were higher than the other samples. These changes are due to the effect that $\mathrm{pH}$ has on the parameters of the crystallite diameter, particle size and also on the cation distribution of the ions in tetrahedral/octahedral spaces.
\end{abstract}

Keywords: Cobalt ferrite; Coprecipitation; Cation distribution; Magnetic propertie

\section{Introduction}

Spinel ferrites with general formula $\mathrm{MFe}_{2} \mathrm{O}_{4}$ or $\mathrm{MO}^{-\mathrm{Fe}_{2} \mathrm{O}_{3}}$ (M: Fe, $\mathrm{Co}, \mathrm{Ni}, \mathrm{Zn}$, etc.) are composed of a unit cell with 32 oxygen atoms in cubic close packed positions, with 8 tetrahedral spaces and 16 occupied octahedral sites. These ferrites are divided into two groups of normal and inverse. In normal spinel, all 8 divalent elements are in tetrahedral positions and all 16 thrivalent elements are in octahedral spaces. Whereas in the inverse spinel, half of the 3-valent elements sit in tetrahedral spaces and the other half placed in the cathedral positions, and the 2-valence elements also occupy the octahedral spaces [1-3].

Cation distribution can effect electron mutation, magnetic exchange interactions, modify magnetic properties, and consequently the use of ferrites [4-7]. Due to this and achieving 
various properties such as magnetic permeability, coercive force, anisotropy constant, saturation magnetization (Ms), mechanical stiffness, physical and chemical stability, the range of use of these materials is varied. Accordingly, much research has been done on the doping effect of different $2 / 3$ valent elements inside the ferrite structures on the synthesis and magnetic properties [5-15]. Among them, cobalt ferrite is interested due to properties such as high magnetic permeability, high coercive force $\left(\mathrm{H}_{\mathrm{C}}\right)(\geq 50 \mathrm{KOe})$, good saturation magnetization $\left(\mathrm{M}_{\mathrm{S}}\right)(80 \mathrm{emu} / \mathrm{gr})$, mechanical hardness and excellent physical and chemical stability. Hence, it is a good candidate for high-density magnetic recording, ferrofluid technology, drug delivery, magnetic resonance imaging (MRI), magnetic hyperthermia (MH) for cancerous tissues and radar absorption materials (RAM) [13].

Cobalt ferrite $\left(\mathrm{CoFe}_{2} \mathrm{O}_{4}\right)$ has an inverse spinel structure. This means that 2-valent cobalt ions are in the octahedral (B) positions and half of the 3-valent iron ions are in the tetrahedral (A) spaces and the other half are in the octahedral sites [14,15]. On the other hand, the zinc element is a low-cost material and it's doping into cobalt ferrite to achieve the desired magnetic properties, especially for hyperthermia applications, is of interest to many researchers. Zinc ferrite is a normal spinel with 2-valent ions in the tetrahedral positions and all 3-valent ions in the octahedral spaces [2]. As a result, zinc doped cobalt ferrite may have a modified spinel structure $\left(\mathrm{Zn}^{2+}{ }_{\mathrm{x}} \mathrm{Fe}^{3+}{ }_{1-\mathrm{x}}\right){ }^{\mathrm{A}}\left[\mathrm{Co}^{2+}{ }_{1-\mathrm{x}} \mathrm{Fe}^{3+}{ }_{1+\mathrm{x}}\right]^{\mathrm{B}} \mathrm{O}_{4}[16]$.

Therefore, the synthesis of zinc cobalt ferrite is of great interest due to its potential application in multiple domains including magnetic hyperthermia. The properties of synthesized ferrites depend on the particles size, morphology and composition [17]. There are a number of methods for preparing magnetic nanoparticles (gaseou, solidous and liquidous phase synthesis). Although uniform nanoparticles have been synthesized using some of these methods, precise control of their size, shape and surface is generally challenging $[8,18,19]$. Among the various methods, Coprecipitation method is an easy and conventional way for the synthesis of magnetic nanoparticles from aqueous salt solutions. Ferrites are usually synthesized in an aqueous medium by chemical reaction according to following equations $[17,19]$ :

$$
\begin{gathered}
\mathrm{M}^{2+}+2 \mathrm{Fe}^{3+}+8 \mathrm{OH}^{-}=\mathrm{MFe} 2 \mathrm{O} 4+4 \mathrm{H} 2 \mathrm{O} \\
\mathrm{Fe}^{3+}+3 \mathrm{OH}^{-}=\mathrm{Fe}(\mathrm{OH}) 3 \\
\mathrm{Fe}(\mathrm{OH}) 3=\mathrm{FeOOH}+\mathrm{H} 2 \mathrm{O} \\
\mathrm{M}^{2+}+2 \mathrm{OH}^{-}=\mathrm{M}(\mathrm{OH}) 2
\end{gathered}
$$

And as a result: 


$$
2 \mathrm{FeOOH}+\mathrm{M}(\mathrm{OH}) 2=\mathrm{MFe} 2 \mathrm{O} 4 \downarrow+2 \mathrm{H} 2 \mathrm{O}
$$

Where $\mathrm{M}$ can be $\mathrm{Fe}^{2+}, \mathrm{Mn}^{2+}, \mathrm{Co}^{2+}, \mathrm{Cu}^{2+}, \mathrm{Mg}^{2+}, \mathrm{Zn}^{2+}, \mathrm{Ni}^{2+}$.

In powder synthesis by coprecipitation method, it is first necessary to precipitate various elements as hydroxide in the reaction system (Equations 1-2 and 1-4), then react with each other to form the desired product phasse after calcination [17]. The $\mathrm{pH}$ value required for the formation of different elements as hydroxide varies. This means that the iron ion may precipitate at a $\mathrm{pH}$ value. This number is another value for the cobalt precipitate and for the zinc ion on another [7]. In general, complete precipitation at pHs between 8 and 14 is expected [7,19]. The size, morphology and composition of magnetic nanoparticles largely depend on the parameters affecting the synthesis process such as the type of salt used (eg chlorides, sulfates, nitrates), type of elements, $\mathrm{M}^{2+} / \mathrm{Fe}^{3+}$ ratio, reaction temperature and $\mathrm{pH}$ value [19]. Therefore, in order to achieve the optimum properties, it is important to investigate the effective parameters on the formation of synthesized particles and how they affect them.

Although the $\mathrm{pH}$ parameter is one of the most effective factors in precipitation, and in particular the final properties of the powders, but so far, little research has been done on how it affects microstructure and magnetic properties of cobalt ferrite. However, Xiaogu Huang [7] has studied the effect of this factor on the properties of electromagnetic loss. Therefore, in this work, the link between $\mathrm{pH}$ parameter and cationic distribution, strain created in the structure, morphology and size of the crystallites have been investigated. Then, the role of these changes on magnetic properties of synthesized nanopowders has been discussed.

\section{Experimental}

\subsection{Materials}

In oredr to synthesis of zinc cobalt ferrite via co-precipitation method iron nitrate $\left(\mathrm{Fe}\left(\mathrm{NO}_{3}\right)_{3}\right.$. $\left.9 \mathrm{H}_{2} \mathrm{O}\right)\left(\mathrm{M}=404 \mathrm{gr} / \mathrm{mol}, \rho=1.68 \mathrm{gr} / \mathrm{cm}^{3}\right.$, Merck $)$, cobalt nitrate $\left(\mathrm{Co}\left(\mathrm{NO}_{3}\right)_{2} \cdot 6 \mathrm{H}_{2} \mathrm{O}\right)(\mathrm{M}=$ $290.93 \mathrm{gr} / \mathrm{mol}, \rho=1.87 \mathrm{gr} / \mathrm{cm}^{3}$, Merck$)$, zinc nitrate $\left(\mathrm{Zn}\left(\mathrm{NO}_{3}\right)_{2} .4 \mathrm{H}_{2} \mathrm{O}\right)(\mathrm{M}=261.39 \mathrm{gr} / \mathrm{mol}$, $\rho=1 \mathrm{gr} / \mathrm{cm}^{3}$ Merck) and sodium hydroxide $(\mathrm{NaOH})$ (Merck) were used as raw materials.

\subsection{Synthesis method}

To determine the effect of $\mathrm{pH}$ value on the process of zinc cobalt ferrite synthesis, at a constant molar ratio of zinc $\left(\mathrm{x}_{\mathrm{zn}}=0.4\right),\left(\mathrm{Co}_{0.6} \mathrm{Zn}_{0.4} \mathrm{Fe}_{2} \mathrm{O}_{4}\right), 0.5 \mathrm{M}$ solutions of each of the 
starting materials were first prepared on a heater stirrer at $400 \mathrm{rpm}$ and $50{ }^{\circ} \mathrm{C}$ for 10 minutes. The prepared solutions were then mixed with each other and the $\mathrm{pH}$ of the resulting system was adjusted to $8,10,11,12$ and 14 with $\mathrm{NaOH}$ solution. After the solution was brought to the desired $\mathrm{pH}$, the resulting solution was stirred at $80{ }^{\circ} \mathrm{C}$ for 5 hours at $700 \mathrm{rpm}$. The precipitates were poured onto filter paper and washed several times with deionized water. It is noteworthy that with the increase of the first $\mathrm{NaOH}$ droplets, the sheet-shaped precipitates were formed in the solution and with the further increase of $\mathrm{NaOH}$ the volume of the precipitates increased and the color of the solution changed from brown-cherry to dark brown. The obtained precipitates were dried for $24 \mathrm{hr}$ at $110{ }^{\circ} \mathrm{C}$. The dried powders were

calcined for $2 \mathrm{~h}$. From now on, specimens at different pHs are introduced as Z4P (814). The number 4 after $Z$ denotes 0.4 mole zinc, and the numbers 8 through 14 after the letter $\mathrm{P}$ indicate the $\mathrm{pH}$ of the solution prepared.

\subsection{Analysis techniques}

Thermogravimetric analysis (TA Instruments, D-32609 Hullhorst, STA 504, Bahr Co. Germany) was taken to determine the calcination temperature. Phase compositions, strain analysis and lattice parameters of samples were analyzed by X-ray diffraction (XRD) (D8 ADVANCE, BRUKER, Germany) analysis. FESEM analysis (Mira 3-XMU) was performed to investigate the microstructural changes, size and morphology of the nanoparticles. The magnetic properties of the samples were also evaluated by VSM (Danesh Pajouh Co. Iran) technique.

\section{Results and discussion}

\subsection{Thermogravimetric analysis}

To determine the calcination temperature, thermogravimetric analysis was taken from the Z4P11 sample which is shown in Figure 1. 


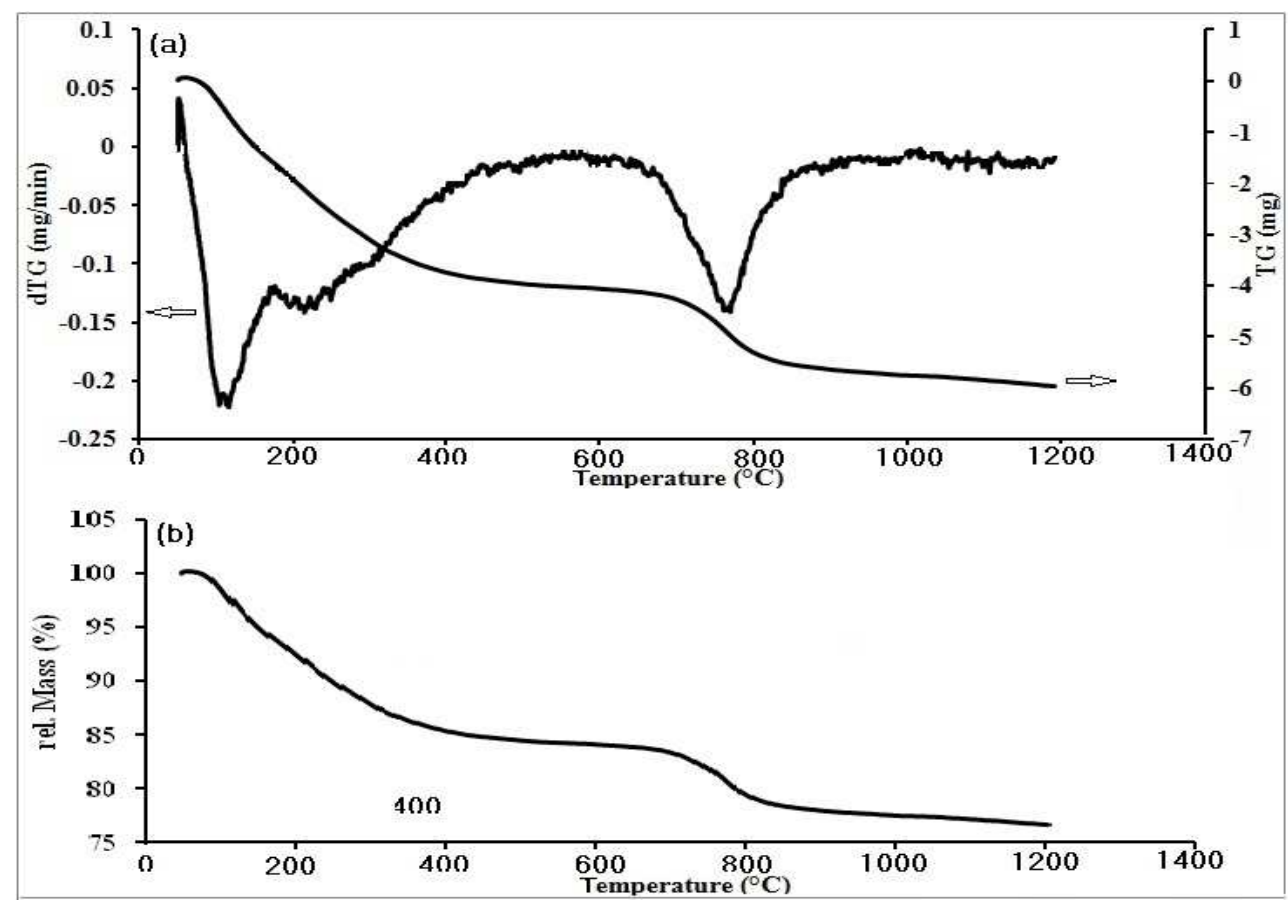

Figure 1- (a) TG/difTG analysis and, (b) rel. Mass analysis of sample containing 0.4 mol of zinc element prepared at $\mathrm{pH}=11$

By examining the TG/dTG diagram (Fig. 1-a), it is observed an endothermic peak at a temperature of about $750{ }^{\circ} \mathrm{C}$, which represents about $18.28 \%$ of the weight loss (Fig. 1-b), hence this temperature was selected as calcination temperature for prepared precipitates. The appearance of endothermic peaks around $100{ }^{\circ} \mathrm{C}$ and in the range of 220 to $460{ }^{\circ} \mathrm{C}$ are attributed to the evaporation of water present in the system as well as the nitrate and $\mathrm{NaOH}$ compounds, respectively [13]. The reaction system of the raw materials can be written as follows:

$$
\begin{aligned}
& 2 \mathrm{Fe}(\mathrm{NO} 3) 3.9 \mathrm{H} 2 \mathrm{O}+0.6 \mathrm{Co}(\mathrm{NO}) 2.6 \mathrm{H} 2 \mathrm{O}+0.4 \mathrm{Zn}(\mathrm{NO} 3) 2.4 \mathrm{H} 2 \mathrm{O}+8 \mathrm{NaOH}= \\
& \mathrm{Co} 0.6 \mathrm{Zn} 0.4 \mathrm{Fe} 2 \mathrm{O} 4+\cdots \\
& 2 \mathrm{Fe}(\mathrm{NO} 3) 3.9 \mathrm{H} 2 \mathrm{O}+6 \mathrm{NaOH}=2 \mathrm{Fe}(\mathrm{OH}) 3+6 \mathrm{NaNO} 3+18 \mathrm{H} 2 \mathrm{O} \\
& 0.6 \mathrm{Co}(\mathrm{NO} 3) 2.6 \mathrm{H} 2 \mathrm{O}+1.2 \mathrm{NaOH}=0.6 \mathrm{Co}(\mathrm{OH}) 2+1.2 \mathrm{NaNO} 3+3.6 \mathrm{H} 2 \mathrm{O} \\
& 0.4 \mathrm{Zn}(\mathrm{NO} 3) 2.4 \mathrm{H} 2 \mathrm{O}+0.8 \mathrm{NaOH}=0.4 \mathrm{Zn}(\mathrm{OH}) 2+0.8 \mathrm{NaNO} 3+1.6 \mathrm{H} 2 \mathrm{O}
\end{aligned}
$$

Also the weight changes of the calcined sample at $750{ }^{\circ} \mathrm{C}$ for 2 hours $(20.94 \%$ weight loss) showed good agreement with the TG analysis. Higher weight loss in calcination is probably due to longer time. 


\subsection{XRD analysis}

The XRD patterns of the synthesize samples at $750{ }^{\circ} \mathrm{C}$ for 2 hours are shown in Figure 2:

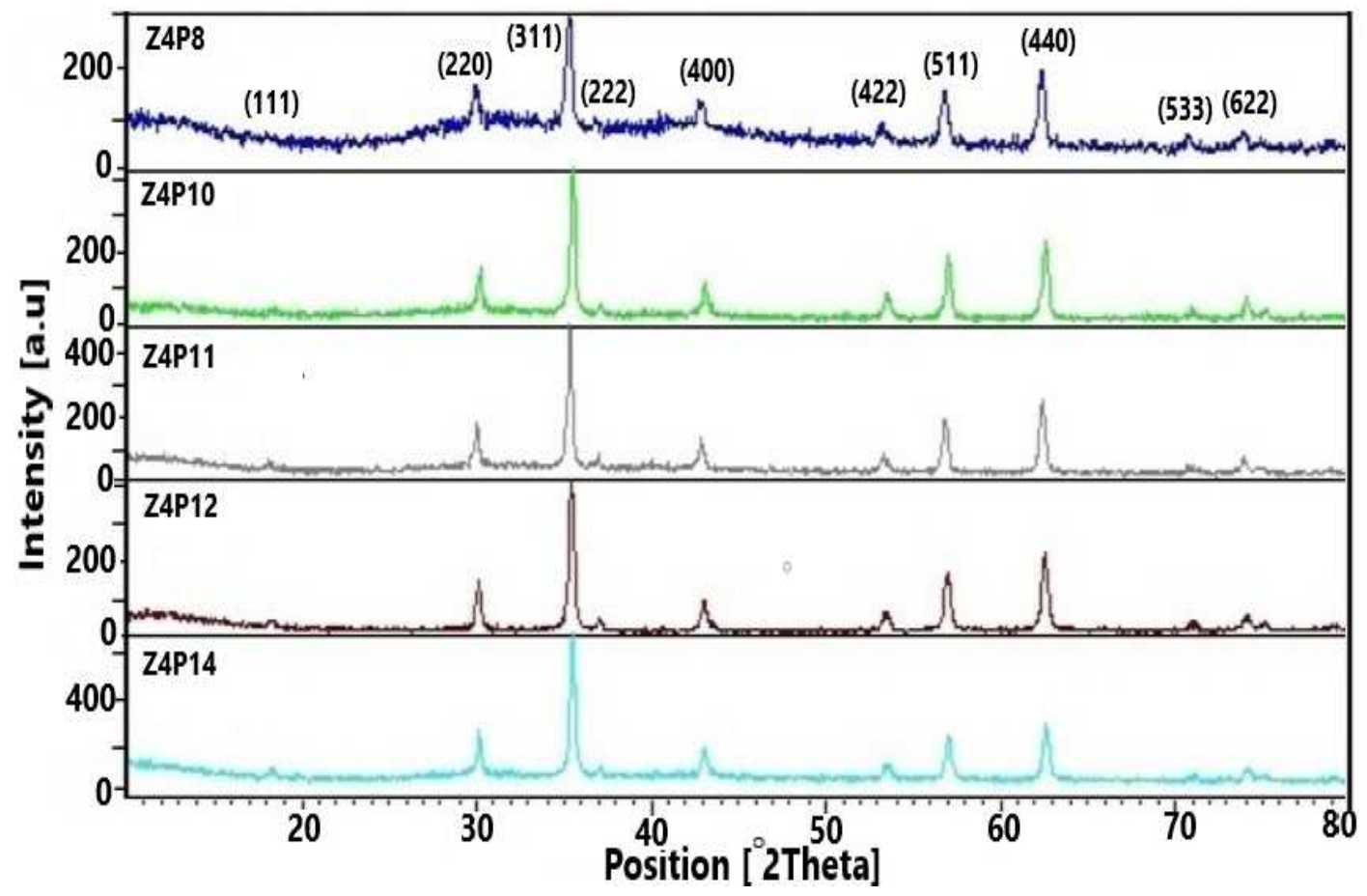

Figure 2- X-ray diffraction patterns of the synthesized powders at $750{ }^{\circ} \mathrm{C}$ for $2 \mathrm{~h}$ from samples prepared at different $\mathrm{pH}$ conditions

Appearance of crystal planes (111), (220), (311), (222), (400), (422), (511), (440), (533) and (622) based on JCPDS Card 00-022-1086 confirms the formation of spinel cubic nanocrystalline structure with $\mathrm{Fd} 3 \mathrm{~m}$ space group in all synthesized sample. This result is different from the work of Xiaogu et al [8] who reported that at $\mathrm{pH}=8$ and at $\mathrm{pHs}$ above 11, some $\mathrm{Fe}_{2} \mathrm{O}_{3}$ and $\mathrm{Zn}(\mathrm{OH})_{2}$ impurities are present in the product, respectively. However, the appearance of higher backgrounds at pHs 8 and 14 than other samples may be attributed to the presence of glass or crystalline phases that were not observed by XRD analysis.

It is well known that the intensity of X-rays scattered from the planes is related to their atomic density. In addition, it has been reported that in solid solutions, including spinel ferrites the intensities depend on the cationic distribution of the elements in different positions [3]. Therefore, for each XRD spectrum, the peak intensity ratio of plane (440) to plane (220) $\leq I_{(440)} / I_{(220)}$ is calculated for each prepared sample that will be listed in Table 1. The corresponding diagram is given in Figure 3. 


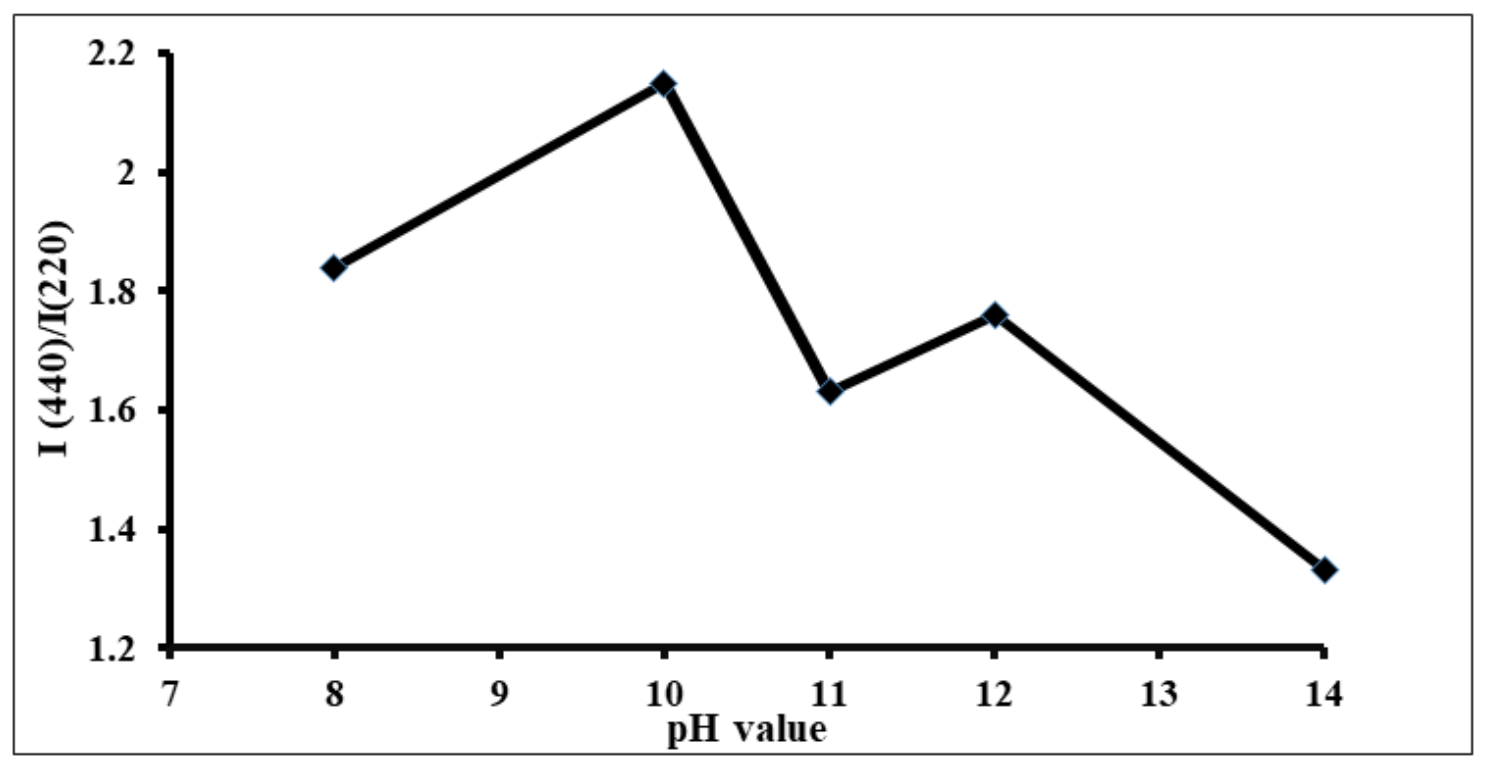

Figure 3-The peak intensity of plane (440) to peak intensity of plane (220), $\left(\mathrm{I}_{(440)} / \mathrm{I}_{(220)}\right)$, for each sample at different $\mathrm{pHs}$

It can be seen in Fig. 3 that the peak intensity ratio $\left(\mathrm{I}_{(440)} / \mathrm{I}_{(220)}\right)$ increases with increasing $\mathrm{pH}$ from 8 to 10 and then decreases to $\mathrm{pH} 11$. It then rises slightly again by changing the $\mathrm{pH}$ to 12 and then decreasing to $\mathrm{pH}=14$. Since the composition and calcination conditions (temperature and time) are constant in all the samples above, it is concluded that the $\mathrm{pH}$ changes in the sample preparation process have caused changes in the cation movement and distribution in the structure. Hence, there have been changes in the peak intensity ratio. Although zinc ions have a large radius $(0.74 \dot{A})$ and naturally prefer to be in a larger space (B site), they sit in tetrahedral position (A site) due to great power of $\mathrm{Zn}-\mathrm{O}$ bonds and crystal field stabilization energy (CFSE) of zinc ions in this space [20, 21]. Thus, by doping zinc into the cobalt ferrite structure, the $\mathrm{Zn}^{2+}$ ions are in the tetrahedron position [21]. This placement of ions means the force applied to the 3 valent iron ions in the tetrahedral space to move to the octahedral position. Assuming, that distribution of elements within the structure of zinc cobalt ferrite can be considered as $\left(\mathrm{Zn}^{2+}{ }_{\mathrm{x}} \mathrm{Fe}^{3+}{ }_{1-\mathrm{x}}\right)^{\mathrm{A}}\left[\mathrm{Co}^{2+}{ }_{1-\mathrm{x}} \mathrm{Fe}^{3+}{ }_{1+\mathrm{x}}\right]^{\mathrm{B}}[3,14,20,21]$.

The Williamson-Hall relation was also used to determine the exact crystalline diameter as well as the strain within them:

$B \cdot \cos (\theta)=(0 \cdot 9 \cdot \lambda / D)+4 \varepsilon \sin (\theta)$

In this equation, $\mathrm{D}$ is the grain size on an angstrom scale, $\lambda$ is the wavelength of $\mathrm{Cu}_{\mathrm{k} \alpha}$ $(1.54056 \dot{\AA}), \mathrm{B}$ is the broadening line at half the peak height in radians, $\varepsilon$ is the lattice strain 
and $\theta$ is the bragg angle of the scattered peak. The line slope is the lattice strain and the point that the line intersects the $\mathrm{y}$ axis is equal to $0.9 . \lambda / \mathrm{D}[22]$.

The results of the Williamson-Hall equation for synthesized powders prepared at different pHs are given in Table 1 and Figure 4.

Table 1- Strain and crystallite diameter of samples prepared at different $\mathrm{pH}$ and calcinated at $750{ }^{\circ} \mathrm{C}$ for 2 hours

\begin{tabular}{|l|l|l|l|l|l|}
\hline samples & Z4P8 & Z4P10 & Z4P11 & Z4P12 & Z4P14 \\
\hline $2 \Theta_{1}\left({ }^{\circ}\right)$ & 35.38 & 35.54 & 35.37 & 35.46 & 35.52 \\
\hline $2 \Theta_{2}\left(^{\circ}\right)$ & 62.42 & 62.65 & 62.46 & 62.60 & 62.66 \\
\hline $2 \Theta_{3}\left({ }^{\circ}\right)$ & 56.83 & 57.05 & 56.88 & 57.00 & 57.07 \\
\hline $2 \Theta_{4}\left(^{\circ}\right)$ & 30.00 & 30.20 & 30.04 & 30.11 & 30.17 \\
\hline $\mathrm{B}_{1}\left({ }^{\circ}\right)$ & 0.39 & 0.26 & 0.26 & 0.32 & 0.27 \\
\hline $\mathrm{B}_{2}\left({ }^{\circ}\right)$ & 0.38 & 0.32 & 0.32 & 0.35 & 0.33 \\
\hline $\mathrm{B}_{3}\left({ }^{\circ}\right)$ & 0.39 & 0.28 & 0.34 & 0.37 & 0.28 \\
\hline $\mathrm{B}_{4}\left({ }^{\circ}\right)$ & 0.38 & 0.25 & 0.22 & 0.31 & 0.20 \\
\hline$\varepsilon$ & $-7 * 10^{-4}$ & $-3.5^{*} 10^{-4}$ & $10^{*} 10^{-4}$ & $1.5^{*} 10^{-4}$ & $10^{*} 10^{-4}$ \\
\hline $\mathrm{D}(\dot{A})$ & 193 & 301 & 478 & 272 & 514 \\
\hline $\mathrm{I}_{(440)} / \mathrm{I}_{(220)}$ & 1.84 & 2.15 & 1.63 & 1.76 & 1.33 \\
\hline
\end{tabular}
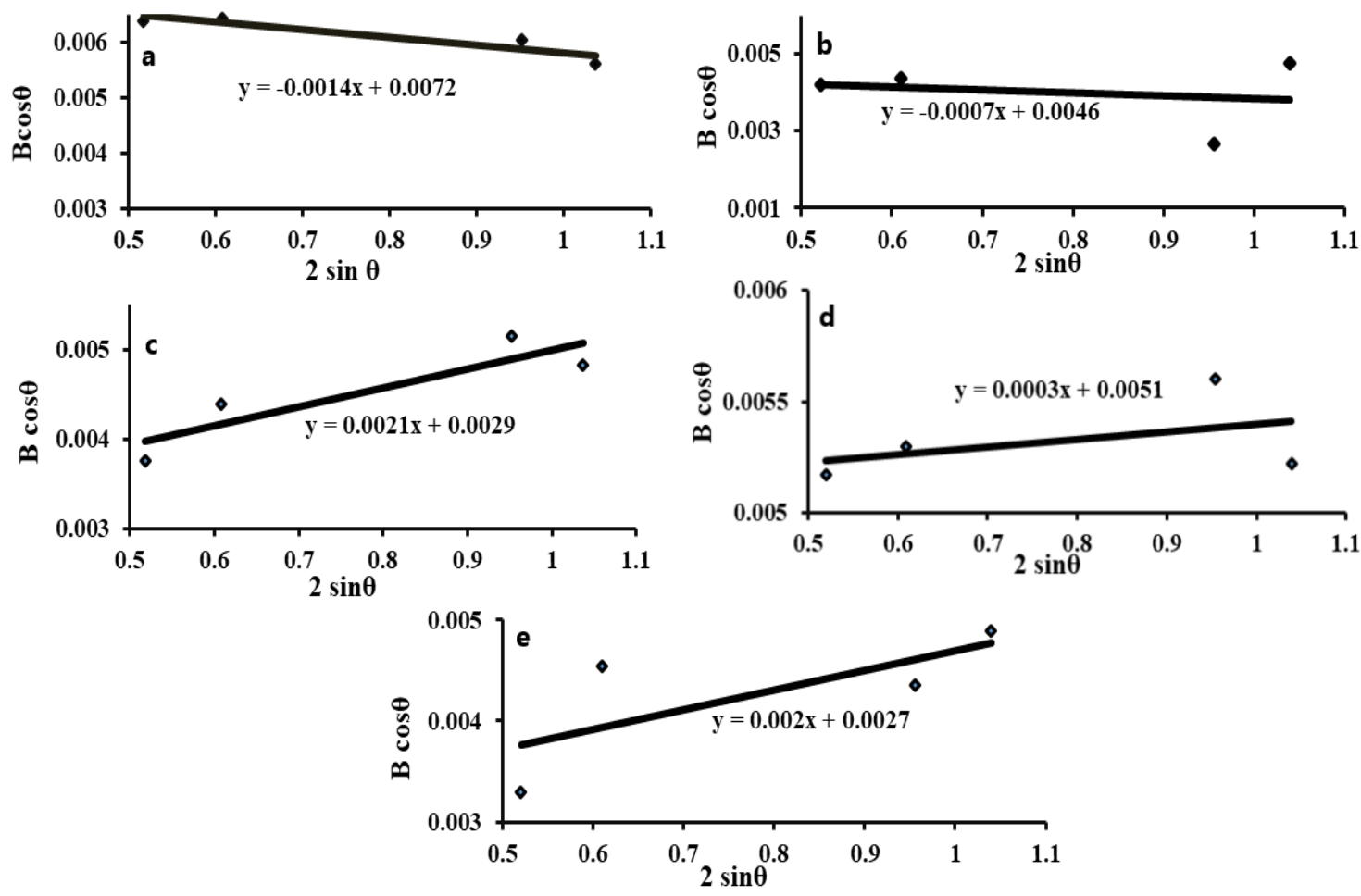

Figure 4- Williamson-Hall diagram of samples synthesized at $750{ }^{\circ} \mathrm{C}$ for $2 \mathrm{~h}$; (a) Z4P8, (b) Z4P10, (c) Z4P11, (d) Z4P12, and (e) Z4P14 
So the trend of changing the crystallite diameters by $\mathrm{pH}$ is shown in Figure 5:

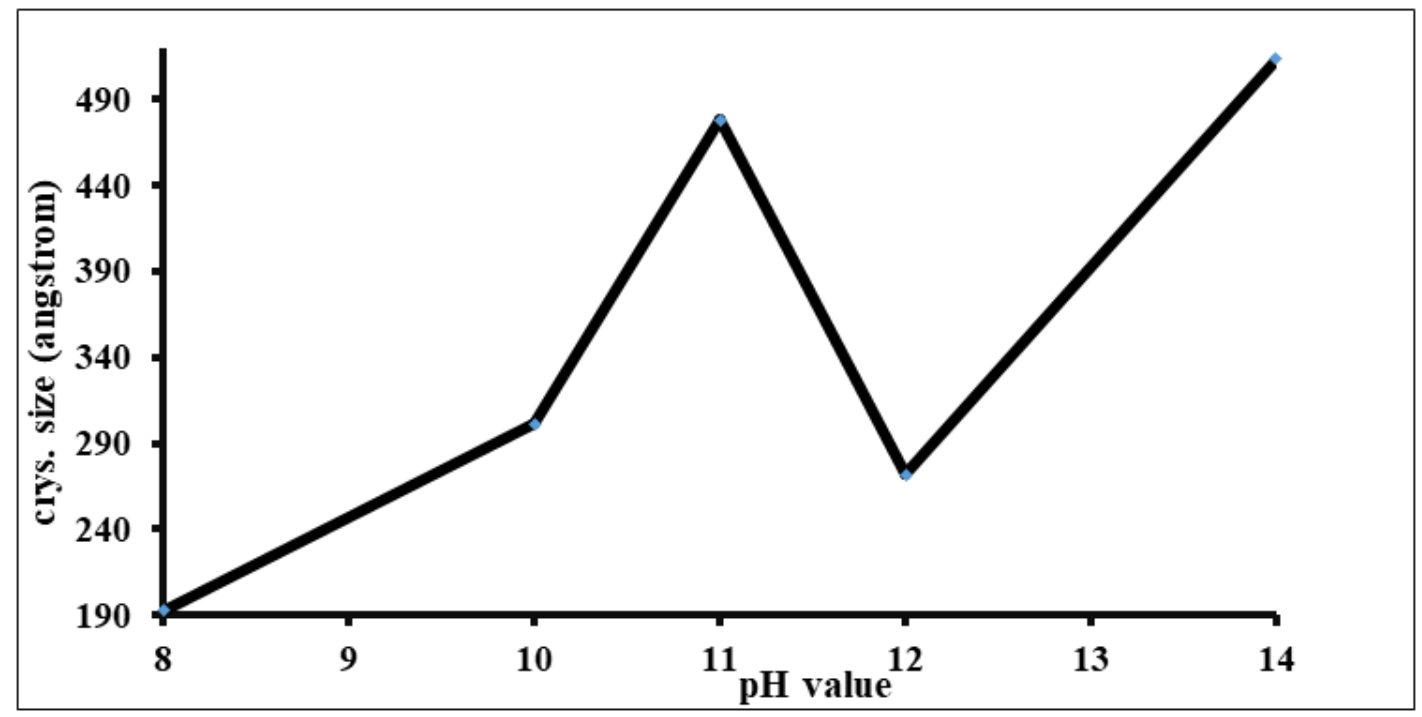

Figure 5- Diagram of the crystallites diameter of the synthesized powders at $750{ }^{\circ} \mathrm{C}$ for $2 \mathrm{~h}$ from zinc doped cobalt ferrites $(0.4$ mole $\mathrm{Zn})$ prepared at different $\mathrm{pH}$ conditions

Interestingly, the calculations and results of the Williamson-Hall equations show how the slope changes, which represents the type of strain (Figure 4, Table 1). Such that, at pHs 8 and 10 , the slope is negative, indicating the type of tensile strain in the system, and the strain slope has decreased from $-7 * 10^{-4}$ to $-3.5^{*} 10^{-4}$. That is, the strain decreased with increasing $\mathrm{pH}$ from 8 to 10 . The crystallite diameter has shown an increasing trend in the $\mathrm{pH}$ range from $19.2 \mathrm{~nm}$ to $30.1 \mathrm{~nm}$ (Table 1, Fig. 5). As the $\mathrm{pH}$ increases to 11 and higher, the slope of the line changes, meaning that the type of strain in the system is changed to pressure (Fig. 4).

It is necessary to explain that in this state the amount of compressive strain in the system decreases with increasing $\mathrm{pH}$ from 11 to 12 and then, it increases again with increasing further $\mathrm{pH}$ to 14 . This trend of strain change is also observed in the amount of crystallite diameters. That is, at $\mathrm{pH}=11$ the crystallite diameter from $47.8 \mathrm{~nm}$ decreased to $27.2 \mathrm{~nm}$, then increased to $51.4 \mathrm{~nm}$ (Figures 4 and 5, Table 1). In other words, the change in the tensile strain to compressive strain increases the diameter of the crystallites, and the more this strain increases, the larger the crystallite diameter and vice versa.

Another point to consider is that the strain values in the different planes also differ for a sample. This behavioral difference is also seen in the intensity of the scattered peaks in these centers. As noted, the $I_{(440)} / I_{(200)}$ ratio, that is, the intensity of the peak scattered on a plane passing through the tetrahedron site with respect to the peak intensity obtained from the plane 
in octahedral space, has changed for different samples (Fig. 3). The presence of lattaice strain and these differences in the structure are due to the effect that $\mathrm{pH}$ has on the movement of ions in network spaces [22].

To determine the lattice parameter varoius methods can be used. The most accurate way is to plot the curve of the lattice parameter in terms of the extrapolate function $\cos ^{2} \theta / \sin \theta[23]$. Therefore, the graph of extrapolate functions for the synthesized powders was drawn (Figure 6). Theoretical density (X-ray density) and specific surface area of the powders were also calculated using the following equations [10,24]:

$$
\rho x=8 M / N a^{3}
$$

Which, $\rho_{\mathrm{x}}$ is theoretical density $\left(\mathrm{gr} / \mathrm{cm}^{3}\right), \mathrm{M}$ is molecular weight of the sample ( $\left.\mathrm{gr} / \mathrm{mole}\right), \mathrm{N}$ is the Avogadro number, a is lattice parameter and 8 denotes the number of unit cells.

$S=6000 / D \rho x$

$D$ is crystallite diameter $(\mathrm{nm}), \rho \mathrm{x}$ is theoretical density $\left(\mathrm{gr} / \mathrm{cm}^{3}\right)$ and $\mathrm{S}$ is specific surface area $\left(\mathrm{m}^{2} / \mathrm{gr}\right)$.

Therefore, the results of the extrapolate functions for the lattice parameter, as well as the theoretical density and specific surface area of the powders are presented in Table 2. 

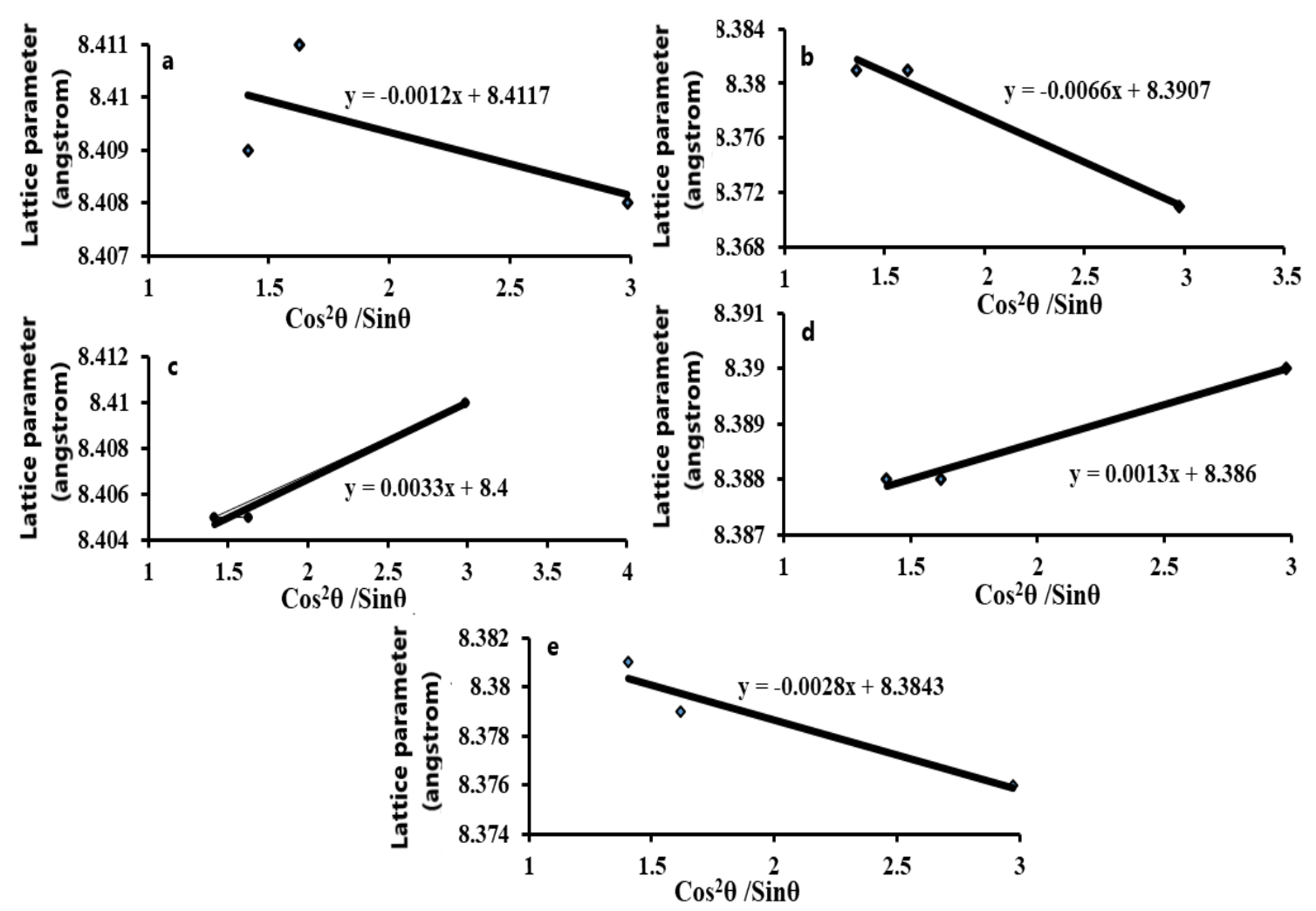

Figure 6- Diagram of extrapolation functions for samples synthesized at $750{ }^{\circ} \mathrm{C}$ for $2 \mathrm{~h}$; (a) Z4P8, (b) Z4P10, (c) Z4P11, (d) Z4P12, and (e) Z4P14

Table 2- lattice parameters, specific surface area and x-ray density of synthesized samples at $750{ }^{\circ} \mathrm{C}$ for 2 hours

\begin{tabular}{|l|l|l|l|l|l|}
\hline samples & Z4P8 & Z4P10 & Z4P11 & Z4P12 & Z4P14 \\
\hline $2 \Theta_{1}\left(^{\circ}\right)$ & 35.38 & 35.54 & 35.37 & 35.46 & 35.52 \\
\hline $2 \Theta_{2}\left({ }^{\circ}\right)$ & 62.42 & 62.65 & 62.46 & 62.60 & 62.66 \\
\hline $2 \Theta_{3}\left(^{\circ}\right)$ & 56.83 & 57.05 & 56.88 & 57.00 & 57.07 \\
\hline $\mathrm{d}_{1}(\AA)$ & 2.535 & 2.524 & 2.536 & 2.530 & 2.526 \\
\hline $\mathrm{d}_{2}(\AA)$ & 1.487 & 1.482 & 1.486 & 1.483 & 1.482 \\
\hline $\mathrm{d}_{3}(\AA)$ & 1.619 & 1.613 & 1.617 & 1.614 & 1.613 \\
\hline $\mathrm{a}(\AA)$ & 8.412 & 8.391 & 8.400 & 8.386 & 8.384 \\
\hline $\mathrm{s}$ & $\pm 16^{*} 10^{-4}$ & $\pm 82^{*} 10^{-4}$ & $\pm 30^{*} 10^{-4}$ & $\pm 12^{*} 10^{-4}$ & $\pm 36^{*} 10^{-4}$ \\
\hline$\rho_{\mathrm{x}}\left(\mathrm{gr} / \mathrm{cm}^{3}\right)$ & 5.303 & 5.342 & 5.325 & 5.352 & 5.356 \\
\hline $\mathrm{S}\left(\mathrm{m}^{2} / \mathrm{gr}\right)$ & 58.76 & 37.26 & 23.57 & 41.24 & 21.82 \\
\hline
\end{tabular}

- (plane order): (311), (440), (511) 


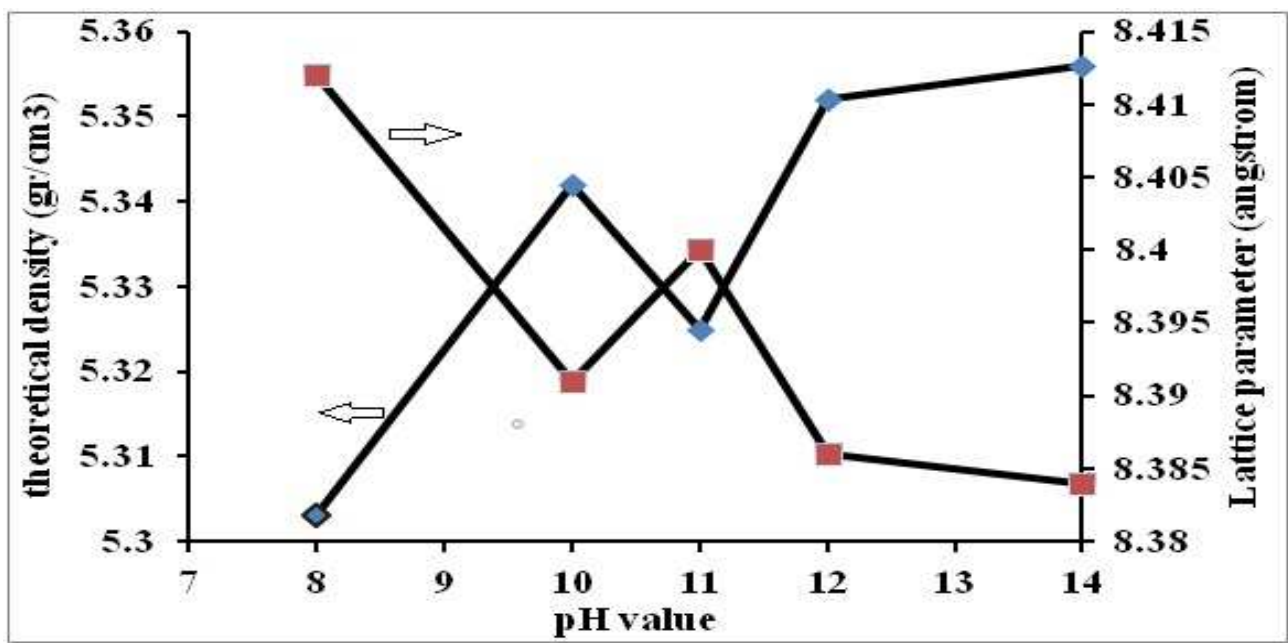

Figure 7- X-ray density graph and lattice parameter of synthesized zinc doped cobalt ferrites $(0.4$ mole $\mathrm{Zn})$ at $750{ }^{\circ} \mathrm{C}$ for $2 \mathrm{~h}$ at different $\mathrm{pHs}$

The effect of $\mathrm{pH}$ on the lattice parameter of synthesized powders is also illustrated in Figure 7. Although in all the powders mentioned, the composition and other synthesis conditions were constant except $\mathrm{pH}$, but the lattice parameter was changed with $\mathrm{pH}$ alteration. However, these changes are very small. This is attributed to changes in the distribution of ions within the structure by the $\mathrm{pH}$ value, just as the amount of strain within the structure also altered (Figure 4). In fact, the relationship between the transition metals and the lattice parameter is justified by the Vegard's law. This rule applies to solid solutions of cobalt ferrite nanoparticles substituted with transition metals $[13,15,25]$. On the other hand, according to Bragg's law $(2 \mathrm{~d} \operatorname{Sin} \theta=\mathrm{n} \lambda)$ and Equation $\left\{\mathrm{d}=\mathrm{a}\left(\mathrm{h}^{2}+\mathrm{k}^{2}+\mathrm{l}^{2}\right)^{0.5}\right\}$ [23], a decrease in the diffraction angle means that the planar distance increases, and thereby the lattice parameter increases. Changing the position of the peaks at various angles (Table 2) for different samples is consistent with this statement. The theoretical density of the samples is also inversely correlated with the lattice parameter according to Equation 3-6, which means that as the lattice parameter increases, the density decreases and vice versa.

\subsection{FESEM/EDX analysis}

FESEM analysis was performed to compare the microstructure of powders prepared under pH 8, 11 and 14 (Fig. 8). 

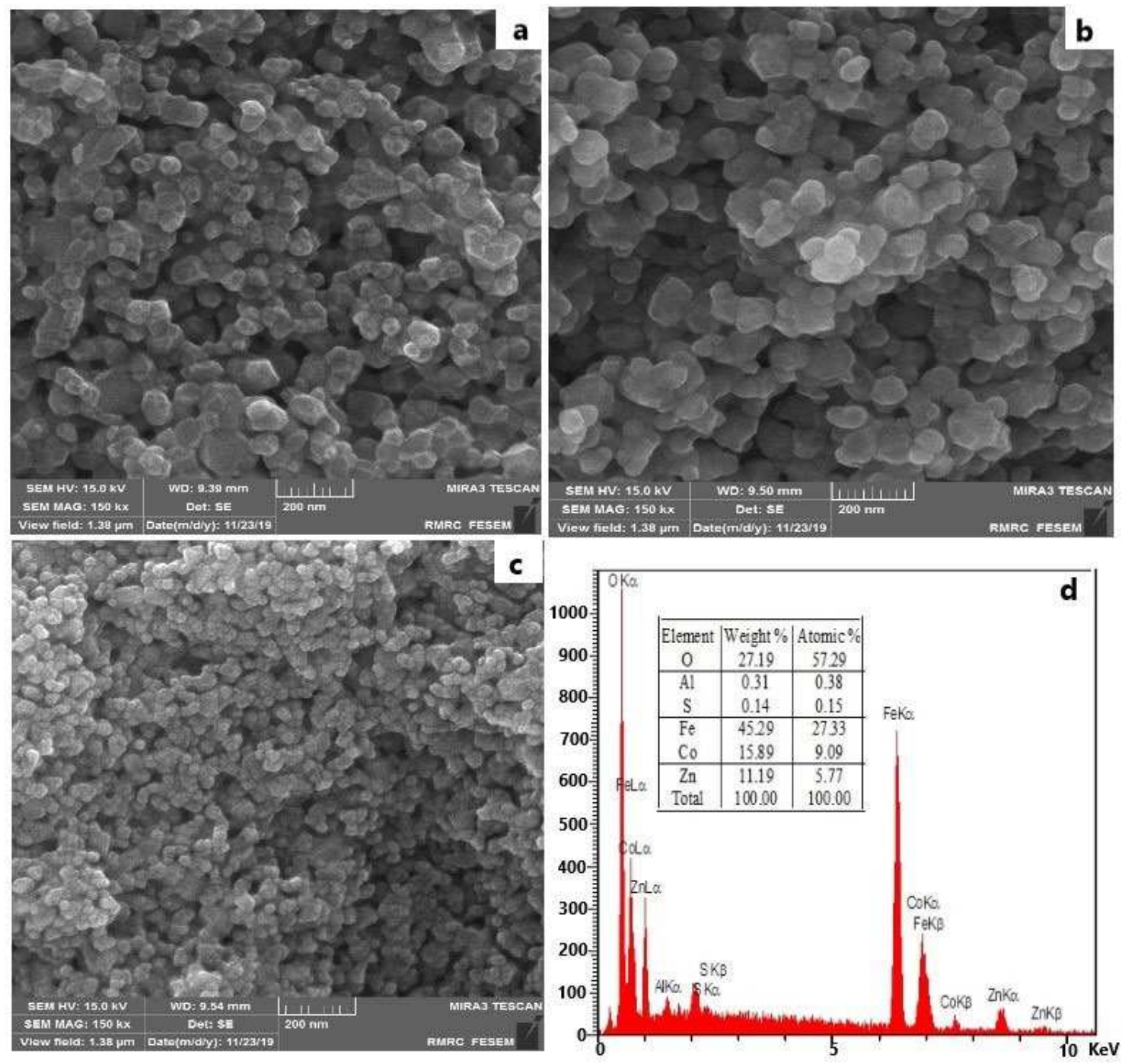

Figure 8- FESEM and EDS analysis of synthesized powders at $750{ }^{\circ} \mathrm{C}$ for $2 \mathrm{~h}$; (a) Z4P8, (b) Z4P11, (c) Z4P14, (d) EDS of Z4P11 specimen

The micrographs of the synthesized powders show that in all samples the particle size range is less than $60 \mathrm{~nm}$ and is relatively uniform. This uniformity is most evident in synthesized powsers at $\mathrm{pH}=11$ (Fig. 8-b). The particle size in the samples prepared at $\mathrm{pH}=11$ is somewhat grater than the other samples. In the powders prepared at $\mathrm{pH} 8$ and especially 11, the cubic shape of the formed particles is quite evident. By increasing the $\mathrm{pH}$ to 14 (Fig. 8-c) the particles appear to be finer, and although the particle size distribution is uniform, the shape of the particles is slightly out of cubic state and look partially spherical. The particles are also axial and the agglomeration of the particles is seen in this sample. Particle agglomeration is due to the higher surface-to-volume ratio of the nanoparticles, which causes high interfacial tension and the particles adhere to each other. In addition, magnetic nanoparticles tend to cluster and stick together due to the interaction of magnetic dipoles [26]. 
It seems that by increasing the $\mathrm{pH}$ and increasing the concentration of $\mathrm{OH}^{-}$ions in the system up to $\mathrm{pH}=11$, a supersaturated lattice is created in the medium and slows down the nucleation. As a result, the rate of grain growth is greater than that of nucleation in this range, which results in the growth of grains and particles, according to Xiaogu Huang et al. [7]. As the $\mathrm{pH}$ increased, especially at $\mathrm{pH}=14$, the particles became smaller (Fig. 8-c). This means that the rate of nucleation is higher than the grain growth rate and the reverse effect of hydroxide concentration on the system, as growth has occurred less, particle's surfaces have increased and agglomeration has taken place. In addition, quantitative EDS analysis for Z4P11 specimen can be seen in Figure 8-d. Z4P11 is approximately the same composition as $\mathrm{Co}_{0.2} \mathrm{Zn}_{0.4} \mathrm{Fe}_{2} \mathrm{O}_{4}$. However, very minor amounts of sulfur and aluminum are present (less than $1 \%$ ), which are very likely to be related to the raw materials consumed.

\subsection{Magnetic properties}

To investigate the effect of $\mathrm{pH}$ value on the magnetic properties of the prepared samples, vibrating sample magnetometer (VSM) analaysis of synthesized powders were performed which are given in Figure 9. The extracted results from these graphs are also presented in Table 3.

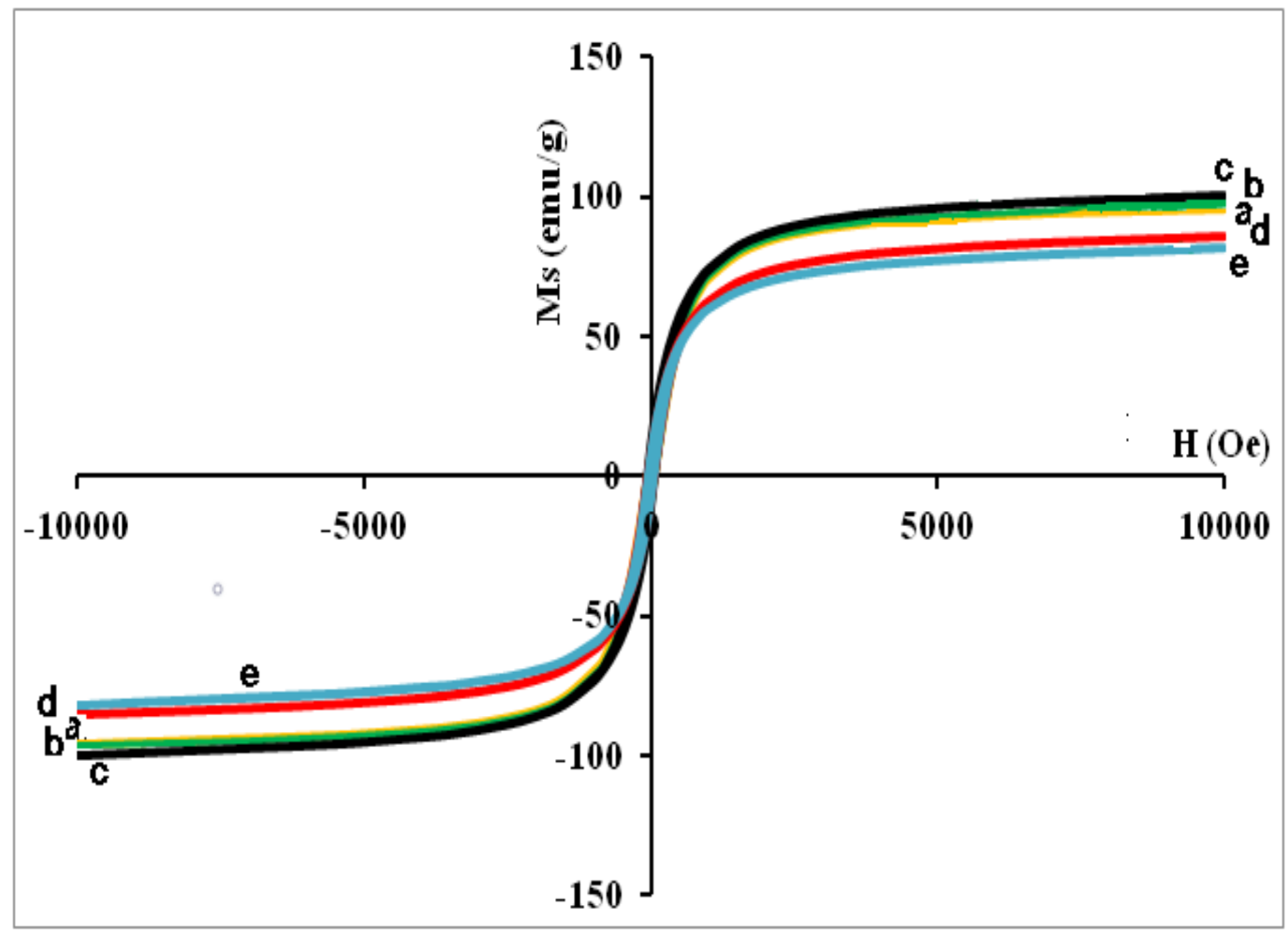

Figure 9- VSM diagram of zinc doped cobalt ferrite (0.4 mole $\mathrm{Zn})$ samples prepared at different $\mathrm{pHs}$ and synthesized at $750{ }^{\circ} \mathrm{C}$ for $2 \mathrm{~h}$; (a) $\mathrm{pH}=8$, (b) $\mathrm{pH}=10$, (c) $\mathrm{pH}=11$, (d) $\mathrm{pH}=12$, and (e) $\mathrm{pH}=14$ 
Table 3- Ms Value of samples synthesized at $750{ }^{\circ} \mathrm{C}$ for $2 \mathrm{~h}$ at different $\mathrm{pHs}$

\begin{tabular}{|l|l|l|l|l|l|}
\hline Magnetic properties & Z4P8 & Z4P10 & Z4P11 & Z4P12 & Z4P14 \\
\hline $\mathrm{M}(\mathrm{emu} / \mathrm{g})$ at $(3000 \mathrm{Oe})$ & 88.39 & 89.49 & 91.54 & 77.21 & 73.67 \\
\hline $\mathrm{M}(\mathrm{emu} / \mathrm{g})$ at $(4000 \mathrm{Oe})$ & 90.80 & 91.86 & 94.16 & 79.72 & 75.98 \\
\hline $\mathrm{M}(\mathrm{emu} / \mathrm{g})$ at $(5500 \mathrm{Oe})$ & 92.60 & 93.94 & 96.48 & 81.91 & 78.07 \\
\hline $\mathrm{M}(\mathrm{emu} / \mathrm{g})$ at $(7000 \mathrm{Oe})$ & 94.02 & 130.51 & 98.01 & 83.46 & 79.61 \\
\hline $\mathrm{M}(\mathrm{emu} / \mathrm{g})$ at $(8500 \mathrm{Oe})$ & 94.77 & 99.028 & 99.18 & 84.57 & 80.81 \\
\hline $\mathrm{Ms}(\mathrm{emu} / \mathrm{g})$ at $(10000 \mathrm{Oe})$ & 95.48 & 65.14 & 100.38 & 85.68 & 81.98 \\
\hline $\mathrm{Hc}(\mathrm{Oe})$ & 150 & 140 & 150 & 140 & 140 \\
\hline $\mathrm{Mr}(\mathrm{emu} / \mathrm{g})$ & 8.79 & 8.50 & 12.16 & 8.72 & 8.89 \\
\hline $\mathrm{Mr} / \mathrm{Ms}$ & 0.09 & 0.13 & 0.12 & 0.10 & 0.10 \\
\hline
\end{tabular}

The amount of $\mathrm{pH}$ value had a significant effect on the saturation magnetization as it can be seen in Figure 10. As soon as $\mathrm{pH}$ changed from 8 to 11, Ms increased from $95.48 \mathrm{emu} / \mathrm{gr}$ to $100.38 \mathrm{emu} / \mathrm{gr}$, and then decreased at pHs 12 and 14 to $85.68 \mathrm{emu} / \mathrm{gr}$ and $81.98 \mathrm{emu} / \mathrm{gr}$, respectively. Since the composition is the same in these samples, the changes in Ms are attributed to the two factors of crystallite diameter and particle size, as well as to the different presence of elements in tetrahedral/octahedral sites. Larger grains tend to have larger magnetic domains. It is easy to move the domain wall, magnetize or non-magnetize with greater grains $[15,27]$. In this way, specimens with larger grains have less $\mathrm{H}_{\mathrm{C}}$ and higher $\mathrm{M}_{\mathrm{s}}$.

On the other hand, FESEM analysis (Fig. 8) and Fig. 5 showed that as the pH changed to 11, the particle size and crystallite diameter increased. Since the existence spins at the particles surfaces are highly disordered, they have decreased with increasing particle size [27, 28]. As a result, the amount of Ms in the Z4P11 sample increased. This increase in $\mathrm{M}_{\mathrm{S}}$, as previously mentioned, is attributed to the migration of $\mathrm{Fe}^{3+}$ ions from the tetrahedral to the octahedral space and the change in interaction by intermediating oxygen ions, known as superexchange interactions, between sublattices $\mathrm{A}$ and $\mathrm{B}$ [3, 26 and 29]. As the $\mathrm{pH}$ increases above 11, the crystallite diameter first decreases and then increases (Table 1). Therefore, the saturation magnetization is expected to decrease and then increase. However, this trend only decreases with increasing $\mathrm{pH}$ (Fig. 10). The micrograph image of the synthesized particles shows that at $\mathrm{pH}=14$ (Fig. 8-c), the synthesized powders have become agglomerated because of small size. So, it is expected that the magnetization of the sample reduced by the same extent. Also, the amount of coercive force for samples was 140-150 Oe (Fig. 10). These values show significant decrease compared to that obtained from the synthesis of zinc cobalt ferrite by Mohammad Sajjad Hossain et al. [16] $\left(\mathrm{H}_{\mathrm{C}}=726.13 \mathrm{Oe}\right)$. This reduction is attributed to the movement of $\mathrm{Co}^{2+}$ ions to the tetrahedral position [3]. 


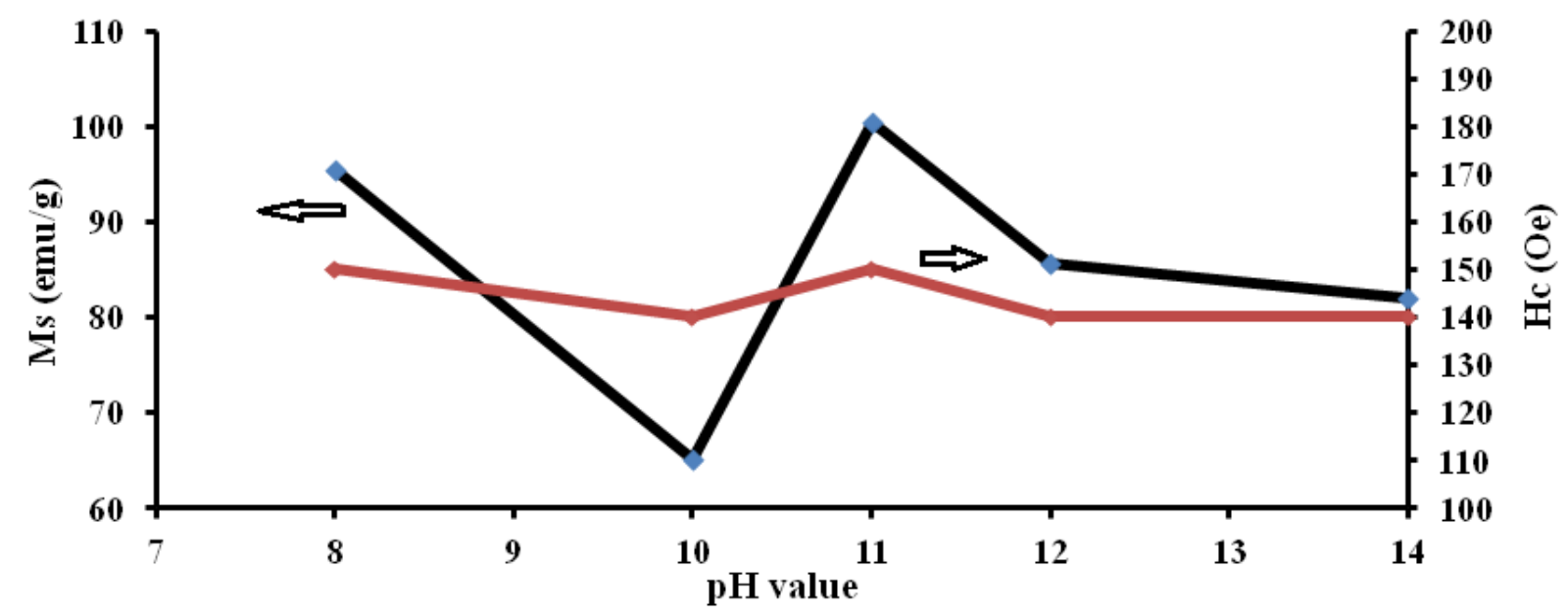

Figure 10- Saturation magnetization and coercive force of $\mathrm{Co}_{0.6} \mathrm{Zn}_{0.4} \mathrm{Fe}_{2} \mathrm{O}_{4}$ samples prepared at different $\mathrm{pHs}$ and synthesized at $750{ }^{\circ} \mathrm{C}$ for $2 \mathrm{~h}$

In addition, the residual ratio $\left(R=M_{r} / M_{S}\right)$ in the synthesized powders was about 0.1 , which means easy change of magnetization path to nearest easy axis of magnetic path after removal of external magnetic field.

For comparison, the amount of saturation magnetization obtained by other researchers synthesizing ferrite nanoparticles is presented in Table 4:

Table 4- Ms Value of different ferrite compositions investigated in different references

\begin{tabular}{|c|c|c|c|}
\hline Composition & Synthesis method & Ms (emu/g) & Reference \\
\hline Zn-Ni ferrites & $\begin{array}{l}\text { Mechanical } \\
\text { alloying }\end{array}$ & 63 & Ghayour et al. [3] \\
\hline $\mathrm{Co}_{0.2} \mathrm{Fe}_{0.8} \mathrm{Fe}_{2} \mathrm{O}_{4}$ & Coprecipitation & 53 & Linh et al. [6] \\
\hline Zn-Mn ferrites & $\begin{array}{l}\text { Coprecipitation- } \\
\text { Hydrothermal }\end{array}$ & 90 & Pilati et al. [11] \\
\hline $\mathrm{Zn}-\mathrm{Co}$ & $\begin{array}{l}\text { Coprecipitation- } \\
\text { Hydrothermal }\end{array}$ & 75 & Pilati et al. [11] \\
\hline $\mathrm{CoFe}_{2} \mathrm{O}_{4}$ & Pechini & 64.92 & Motavallian et al.[15] \\
\hline $\mathrm{Cd}_{0.1} \mathrm{Co}_{0.9} \mathrm{Zr}_{0.05} \mathrm{Fe}_{1.95}$ & Pechini & 67.71 & Motavallian et al.[15] \\
\hline $\mathrm{Fe}_{3} \mathrm{O}_{4}$ & $\begin{array}{l}\text { in situ and semi- } \\
\text { two-step co- } \\
\text { precipitation }\end{array}$ & 50.70 & Shaterabadi et al. [26] \\
\hline $\mathrm{Mg}_{\mathrm{X}}-\mathrm{\gamma} \mathrm{Fe}_{2} \mathrm{O}_{3}$ & Coprecipitation & 70 & Jang et al. [29] \\
\hline $\mathrm{Co}_{0.5} \mathrm{Ni}_{0.37} \mathrm{Cu}_{0.13} \mathrm{Fe}_{2} \mathrm{O}_{4}$ & $\begin{array}{l}\text { sol-gel auto } \\
\text { combustion }\end{array}$ & 65.29 & Ramakrishna et al. [30] \\
\hline $\mathrm{Co}_{0.5} \mathrm{Zn}_{0.37} \mathrm{Cu}_{0.13} \mathrm{Fe}_{2} \mathrm{O}_{4}$ & $\begin{array}{l}\text { sol-gel auto } \\
\text { combustion }\end{array}$ & 50.35 & Ramakrishna et al. [30] \\
\hline $\mathrm{CoFe}_{2} \mathrm{O}_{4}$ & $\begin{array}{l}\text { Mechanical } \\
\text { Alloying }\end{array}$ & 78 & Mahdikhah et al. [31] \\
\hline $\mathrm{Fe}_{3} \mathrm{O}_{4}$ & Coprecipitation & 15.92 & $\begin{array}{c}\text { Salavati-Niasari et al. } \\
{[32]}\end{array}$ \\
\hline $\mathrm{Ni}-\mathrm{Zn}$ ferrites & Coprecipitation & 52 & Ahmad et al. [33] \\
\hline
\end{tabular}




\begin{tabular}{|c|c|c|c|}
\hline $\mathrm{Cu}_{0.3} \mathrm{Zn}_{0.2} \mathrm{Mg}_{0.5} \mathrm{Fe}_{2} \mathrm{O}_{4}$ & Coprecipitation & 52 & Ansari et al. [34] \\
\hline $\mathrm{CoFe}_{2} \mathrm{O}_{4}$ & solvothermal & 98 & Lavorato et al. [35] \\
\hline cobalt & solvothermal & 158 & Kotoulas et al. [36] \\
\hline $\mathrm{Ce}_{\mathrm{x}} \mathrm{Fe}_{3-\mathrm{x}} \mathrm{O}_{4}$ & Coprecipitation & 62 & Shaw et al. [37] \\
\hline $\mathrm{Zn}_{0.2} \mathrm{Co}_{0.8} \mathrm{Fe}_{2} \mathrm{O}_{4}$ & $\begin{array}{c}\text { hydrothermal } \\
\text { method }\end{array}$ & 76.6 & Topkaya et al. [38] \\
\hline
\end{tabular}

The saturation magnetization of the present work $(100.38 \mathrm{emu} / \mathrm{gr})$ is almost greater than the Ms of most ferrite nanoparticles synthesized by others (Table 4). In addition, according to Wuhlfarth's theory, anisotropic constant $(\mathrm{K})$ and magnetic moment $\left(\mathrm{n}_{\mathrm{B}}\right)$ for the formula unit are obtained by Equations (3-8) and (3-9) [4,16,39]:

$$
\begin{gathered}
H c=0.98 K / M s \\
\boldsymbol{n}_{B}=(M w \cdot M s) / 5585
\end{gathered}
$$

Where $\mathrm{Mw}$ is molecular weight. Therefore, the values of $\mathrm{K}$ and $\mathrm{n}_{\mathrm{B}}$ are given in Table 5, and their changes vs. $\mathrm{pH}$ parameter are shown in Figure 11.

Table 5- Magnetic moment and anisotropic constant of samples prepared at different $\mathrm{pH}$ and synthesized at $750{ }^{\circ} \mathrm{C}$ for 2 hours

\begin{tabular}{|l|l|l|l|l|l|}
\hline $\begin{array}{l}\text { Magnetic } \\
\text { properties }\end{array}$ & Z4P8 & Z4P10 & Z4P11 & Z4P12 & Z4P14 \\
\hline $\mathrm{K}(\mathrm{erg} / \mathrm{oe})$ & 14614.33 & 9305.63 & 15357.70 & 12239.34 & 11711.98 \\
\hline $\mathrm{n}_{\mathrm{B}}\left(\mu_{\mathrm{B}} /\right.$ f.u $)$ & 4.06 & 2.77 & 4.27 & 3.64 & 3.49 \\
\hline
\end{tabular}

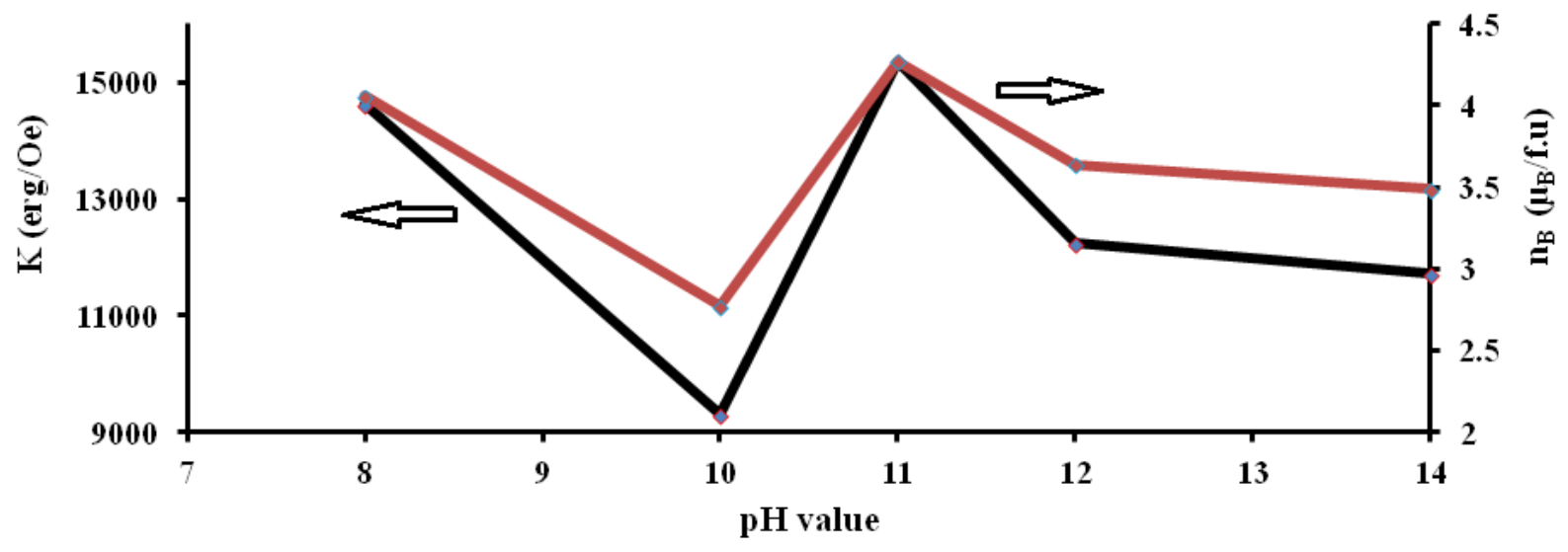

Figure 11- Anisotropic constant and Bohr magneton of $\mathrm{Co}_{0.6} \mathrm{Zn}_{0.4} \mathrm{Fe}_{2} \mathrm{O}_{4}$ samples prepared at different pHs and synthesized at $750{ }^{\circ} \mathrm{C}$ for $2 \mathrm{~h}$

Bohr magneton and anisotropic constant of the prepared samples behaved alike similar to what observed for saturation magnetization. The value of magnetic moment in the structure of the nanoparticles depends on momentum differences between octahedral and tetrahedral 
spaces. Therefore, based on the changes seen in Figure 11, it can be deduced as $\mathrm{pH}$ amount rises, some $\mathrm{Fe}^{3+}$ ions moves to $\mathrm{B}$ sites from $\mathrm{A}$ sites, while $\mathrm{Co}^{2+}$ would be forced to go tetrahedral positions. This means reduction of cobalt ion concentration in octahedral space, and consequently decreases in anisotropic constant which enhances magnetic moment.

\section{Conclusions}

Single phase zinc-doped cobalt ferrite nanoparticles prepared under various pHs via coprecipitation method. The $\mathrm{pH}$ value had a significant influence in the structural and magnetic properties of the synthesized ferrites. FESEM micrographs showed relatively uniform distribution of spherical-like grains in the range of less than $60 \mathrm{~nm}$. The crystallite size of the spherical nanoparticles changed at different pHs. These changes are attributed to the concentration of $\mathrm{OH}^{-}$ions in the system and its effect on the nucleation rate and grain growth. Saturation magnetization, Bohr magneton and anisotropic constant of the prepared samples behaved alike, approximately as observed for crystallite sizes at various pHs. The Hc was in the range of 140-150 Oe for the all synthesized powders. These variations can be attributed to the change in crystallite diameter, particle size, and cation distribution in tetrahedral/octahedral positions.

\section{Acknowledgements}

The authors would like to thank the Department of Materials Engineering, Babol Noshirvani University of Technology.

\section{References}

[1] Callister WD, Rethwisch DG. Materials Science and Engineerin-An introduction, 8th edn. Hoboken, USA: John Wiley \& Sons, 2013.

[2] Askeland DR, Fulay PP, Wright WJ. The Science and Engineering of Materials, 6th edn. Stamford, USA: Cengage Learning Inc. 2010.

[3] Ghayour H, Abdellahi M, Ozada N, et al. Hyperthermia application of zinc doped nickel ferrite nanoparticles .J Phys Chem Solids 2017, 111: 462-472.

[4] Phor L, KUMAR V. Structural, thermomagnetic, and dielectric properties of $\mathrm{Mn}_{0.5} \mathrm{Zn} 0.5 \mathrm{Gd} x \mathrm{Fe} 2-x \mathrm{O} 4$ ( $x=0,0.025,0.050,0.075$, and 0.1). J Adv Ceram 2020, 9(2): $243-$ 254. 
[5] Andhare DD, Patade SR, Kounsalye JS, et al. Effect of Zn doping on structural, magnetic and optical properties of cobalt ferrite nanoparticles synthesized via Co-precipitation method. Physica B: Physics of Condensed Matter 2020, https://doi.org/10.1016/j.physb.2020.412051 [6] Linh PH, Anh TN, Nam PH, et al A Facile Ultrasound Assisted Synthesis of DextranStabilized $\mathrm{Co}_{0.2} \mathrm{Fe}_{0.8} \mathrm{Fe}_{2} \mathrm{O}_{4}$ Nanoparticles for Hyperthermia Application. IEEE Trans Magn 2018, 54: 1-6.

[7] Huang X, Zhang J, Wang W, et al. Effect of $\mathrm{pH}$ value on electromagnetic loss properties of Co-Zn ferrite prepared via coprecipitation method. J Magn Mag Mater 2016, 405: 36-41.

[8] S Fonseca GC, Neiva LS, Bonifácio AR, et al. Tunable Magnetic and Electrical Properties of Cobalt and Zinc Ferrites $\mathrm{Co}_{1-\mathrm{X}} \mathrm{Zn}_{\mathrm{X}} \mathrm{Fe}_{2} \mathrm{O}_{4}$ Synthesized by Combustion Route. Mater Res 2018, 21(3): e2017086.

[9] Vinuthna C, Naidu KB, Sekhar C, et al. Magnetic and antimicrobial properties of cobaltzinc ferrite nanoparticles synthesized by citrate-gel method. Int J Appl Ceram Technol 2019, 16: $1944-1953$.

[10] Lin Q, Xu J, Yang F, et al. Magnetic and Mössbauer Spectroscopy Studies of ZincSubstituted Cobalt Ferrites Prepared by the Sol-Gel Method. Materials 2018, 11:1799.

[11] Pilati V, Gomes RC, Gomide G, et al. Core/Shell Nanoparticles of Non-Stoichiometric $\mathrm{Zn}-\mathrm{Mn}$ and Zn-Co Ferrites as Thermosensitive Heat Sources for Magnetic Fluid Hyperthermia J Phys Chem C 2018, 122: 3028-3038.

[12] S Sunil, Shelke SB, Birajdar AA, et al. Hopping mechanism and cation distribution studies in $\mathrm{Y}^{3+}$ doped cobalt ferrite nanoparticles. Int Res J Sci Eng A 2018, 5: 57-60.

[13] N Sanp, Berndt CC, Wen C, et al. Transition metal-substituted cobalt ferrite nanoparticles for biomedical applications. Acta Biomater 2013, 9: 5830-5837.

[14] Shirsath SE, Mane ML, Yasukawa Y, et al. Self-ignited high temperature synthesis and enhanced super-exchange interactions of $\mathrm{Ho}^{3+}-\mathrm{Mn}^{2+}-\mathrm{Fe}^{3+}-\mathrm{O}^{2-}$ ferromagnetic nanoparticles. Phys Chem Chem Phys 2014, 16: 2347-2357.

[15] Motavallian P, Abasht B, Mirzaee O, et al. Correlation between structural and magnetic properties of sub-stituted (Cd, Zr) Cobalt ferrite nanoparticles. Chin J Phys 2019, 57: 6-13.

[16] Hossain MS, Alamy MB, Shahjahan M, et al. Synthesis, structural investigation, dielectric and magnetic properties of $\mathrm{Zn}^{2+}$-doped cobalt ferrite by the sol-gel technique. $J$ Adv Dielect 2018, 8: 18-30. 
[17] Daoush WM. Co-Precipitation and Magnetic Properties of Magnetite Nanoparticles for Potential Biomedical Applications. J Nanomed Res 2017, 5(3): 00118.

[18] Mathew S, Juang RS. An overview of the structure and magnetism of spinel ferrite nanoparticles and their synthesis in microemulsions. Chem Eng J 2007, 129: 51-65.

[19] Sodaee T, Ghasemi A, Shoja-Razavi R. Microstructural Characteristics and Magnetic Properties of Gadolinium-Substituted Cobalt Ferrite Nanocrystals Synthesized by Hydrothermal Processing. J Clust Sci 2016, 27: 1239.

[20] Raghuvanshi S, Mazaleyrat F, Kane SN. Time evolution of structural and magnetic properties of Ni-Zn nano ferrite: an opinion. J Mater Sci 2017, 1: 1-2.

[21] Mao J, Hou X, Huang F, et al. Zn substitution $\mathrm{NiFe}_{2} \mathrm{O}_{4}$ nanoparticles with enhanced conductivity as high-performances electrodes for lithium ion batteries. J Alloys Compd 2016, 66: $265-274$.

[22] Kumar L, Kumar P, Narayan A, et al. Rietveld analysis of XRD patterns of different sizes of nanocrystalline cobalt ferrite. Int Nano Lett 2013, 3:8.

[23] Cullity B D. Elements of X-ray Diffraction, 2nd edn. California, USA: Addison-Wesley Publishing Company, 1978.

[24] Kumar H, Srivastava RC, Negi P, et al. Dielectric behavior of cobalt ferrite nanoparticles. IJEEE 2013, 2: 59-66.

[25] Zhang Y, Wen D. Influence of RE/Mn ( $\mathrm{RE}=\mathrm{La}, \mathrm{Nd}$ and $\mathrm{Gd})$ ratios on the Infrared Absorption and Emission Properties of Co-Zn Ferrites. J Adv Mater Res 2011, 217: 311-316.

[26] Shaterabadi Z, Nabiyouni G, Soleymani M. Physics responsible for heating efficiency and self-controlled temperature rise of magnetic nanoparticles in magnetic hyperthermia therapy. Prog Biophys Mol Bio 2018, 133: 9-19.

[27] Kafrouni L, Savadogo O. Recent progress on magnetic nanoparticles for magnetic Hyperthermia. Prog Biomater 2016, 5: 147-160.

[28] Jang JT, Bae S. Mg shallow doping effects on the ac magnetic self-heating characteristics of $\gamma$-Fe2O3 superparamagnetic nanoparticles for highly efficient hyperthermia. Appl Phys Lett 2017, 111:183703.

[29] Thorat LM, Patil JY, Nadargi DY, et al. $\mathrm{Co}^{2+}$ substituted $\mathrm{Mg}-\mathrm{Cu}-\mathrm{Zn}$ ferrite: Evaluation of structural, magnetic, and electromagnetic properties. J Adv Ceram 2018, 7(3): 207-217.

[30] Ramakrishna A, Murali N, Margarette SJ, et al. Adv Powd Techn 2018, https://doi.org/10.1016/j.apt.2018.07.005. 
[31] Mahdikhah V, Ataie A, Babaei A, et al. Control of structural and magnetic haracteristics of cobalt ferrite by postcalcination mechanical milling. J Phys Chem Solids 2019, 134: 286294.

[32] Salavati NM, Mahmoudi T, Amiri O. Easy Synthesis of Magnetite Nanocrystals via Coprecipitation Method. J Clust Sci 2012, 23:597-602.

[33] Ahmad A, Bae H, Rhee I, et al. Poly(ethyleneglycol)-coated $\mathrm{Ni}_{0.65} \mathrm{Zn}_{0.35} \mathrm{Fe}_{2} \mathrm{O}_{4}$ nanoparticles for hyperthermia applications. J Korean Phys Soc 2017, 70(6): 615-620.

[34] Ansari M, Bigham A, Hassanzadeh SA, et al. Copper-substituted spinel Zn-Mg ferrite nanoparticles as potential heating agents for hyperthermia. J Am Ceram Soc 2018, 101(8) [35] Lavorato G, Lima E, Mansilla MV, et al. Bifunctional $\mathrm{CoFe}_{2} \mathrm{O}_{4} / \mathrm{ZnO}$ Core/Shell Nanoparticles for Magnetic Fluid Hyperthermia with Controlled Optical Response. J Phys Chem C 2018, 122(5): 19189-19196.

[36] Kotoulas A, Dendrinou SC, Sarafidis C, et al. Carbon-encapsulated cobalt nanoparticles: synthesis, properties, and magnetic particle hyperthermia efficiency. J Nanopart Res 2017, 19:399.

[37] Shaw SK, Alla SK, Meena SS, et al. Stabilization of temperature during magnetic hyperthermia by Ce substituted magnetite nanoparticles. J Magn Mag Mater 2017, 434: 181186.

[38] Topkaya R, Baykal A, Demir A. Yafet-Kittel-type magnetic order in Zn-substituted cobalt ferrite nanoparticles with uniaxial anisotropy. J Nanopart Res 2013, 15:1359.

[39] Zeeshan T, Anjum S, Iqbal H, et al. Substitutional effect of copper on the cation distribution in cobalt chromium ferrites and their structural and magnetic property. Mater Sci-Poland 2018, 36(2): 255-263. 
Figures

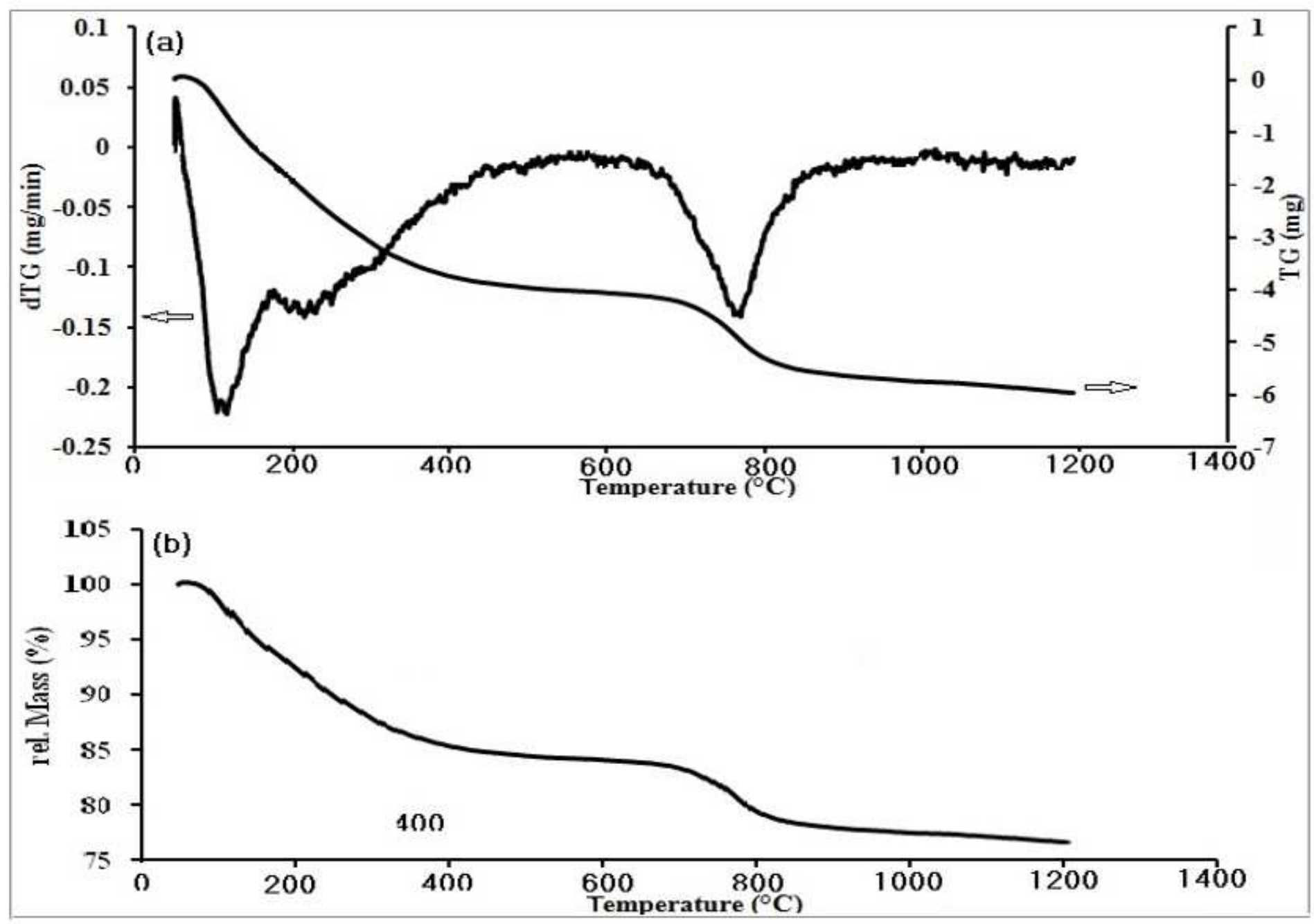

Figure 1

(a) TG/difTG analysis and, (b) rel. Mass analysis of sample containing $0.4 \mathrm{~mol}$ of zinc element prepared at $\mathrm{pH}=11$ 


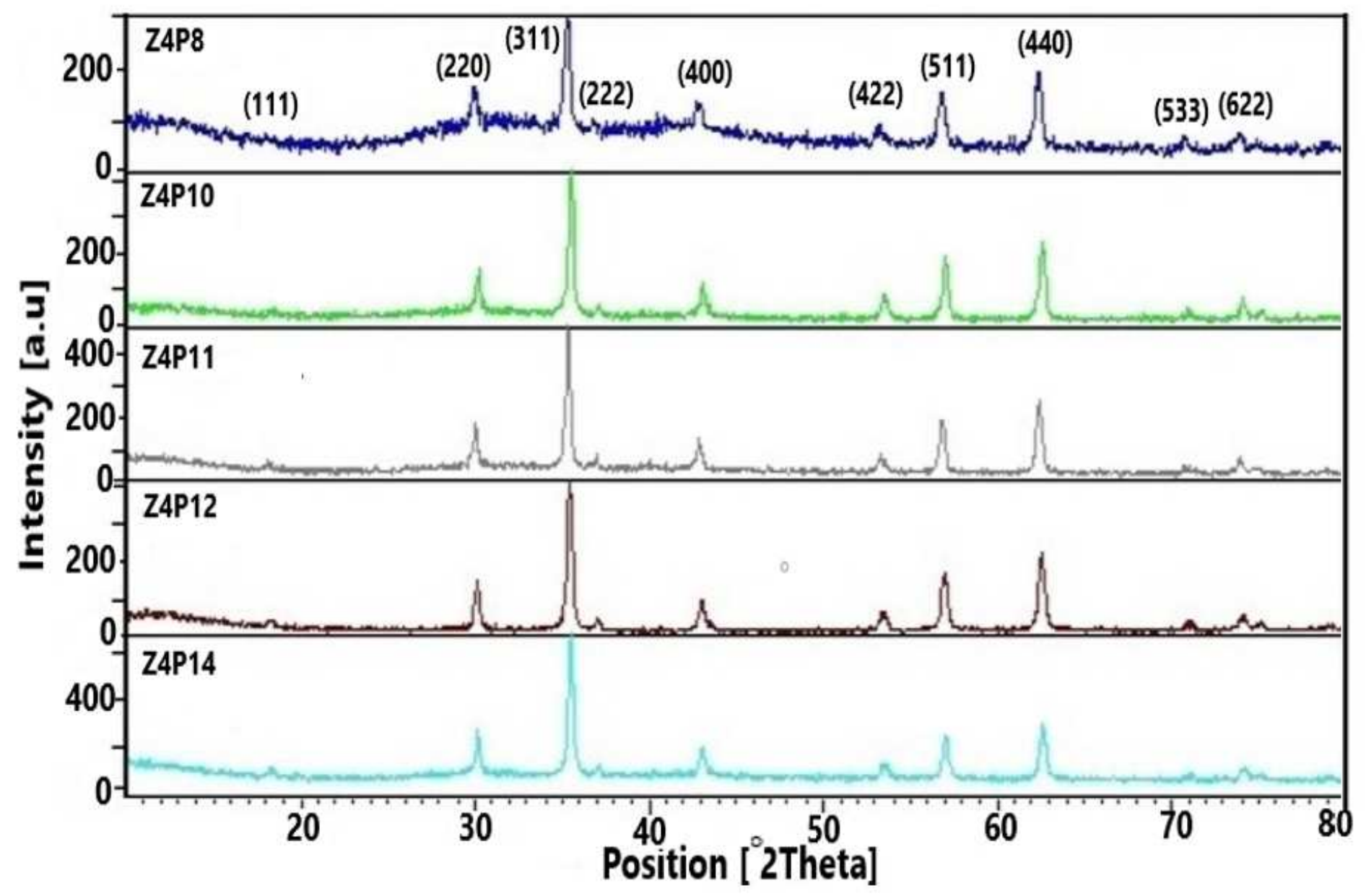

Figure 2

X-ray diffraction patterns of the synthesized powders at $750{ }^{\circ} \mathrm{C}$ for $2 \mathrm{~h}$ from samples prepared at different $\mathrm{pH}$ conditio 


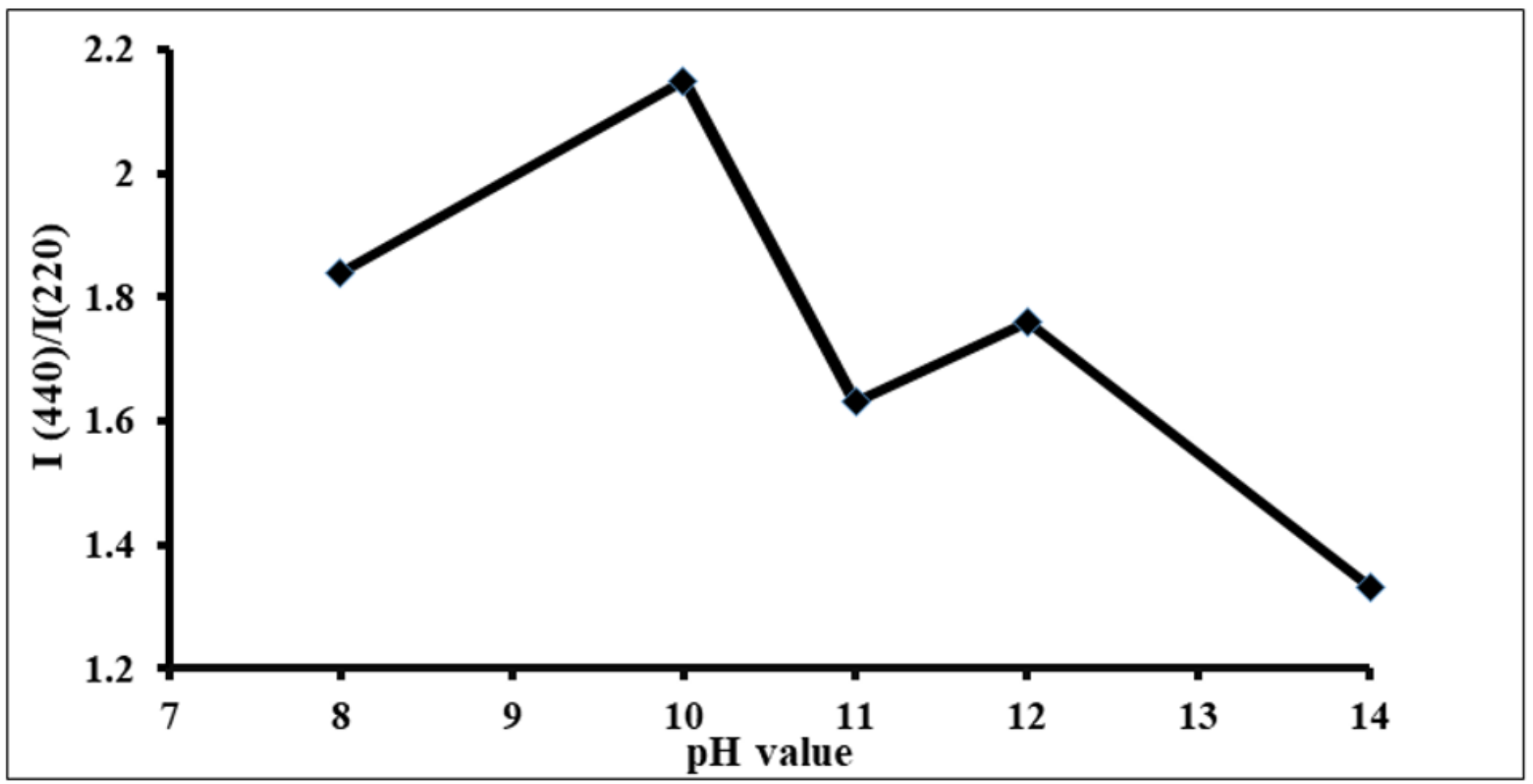

Figure 3

The peak intensity of plane (440) to peak intensity of plane (220), (I(440)/I(220)), for each sample at different pHs 

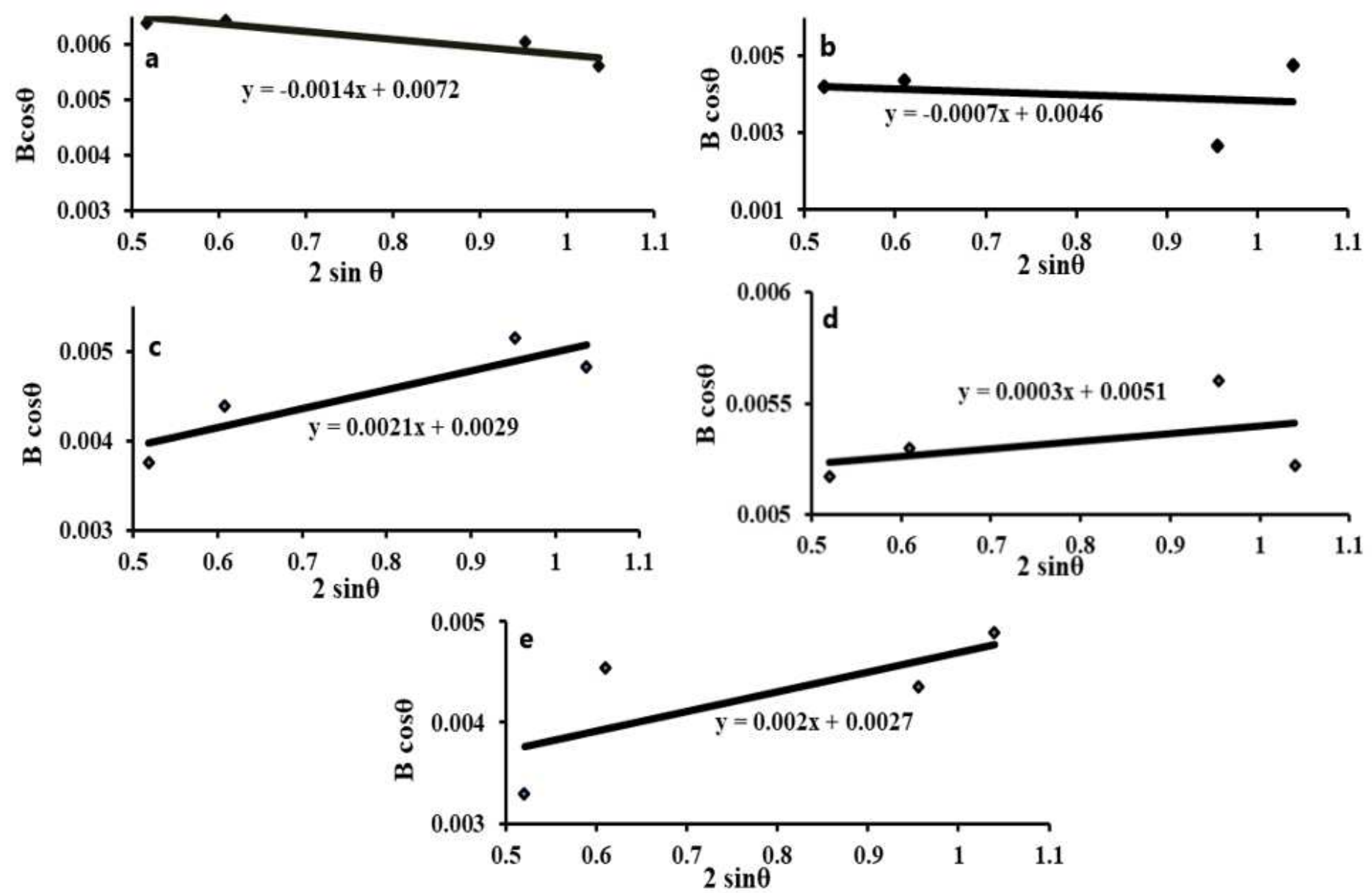

Figure 4

Williamson-Hall diagram of samples synthesized at $750{ }^{\circ} \mathrm{C}$ for $2 \mathrm{~h}$; (a) Z4P8, (b) Z4P10, (c) Z4P11, (d) Z4P12, and (e) Z4P14 


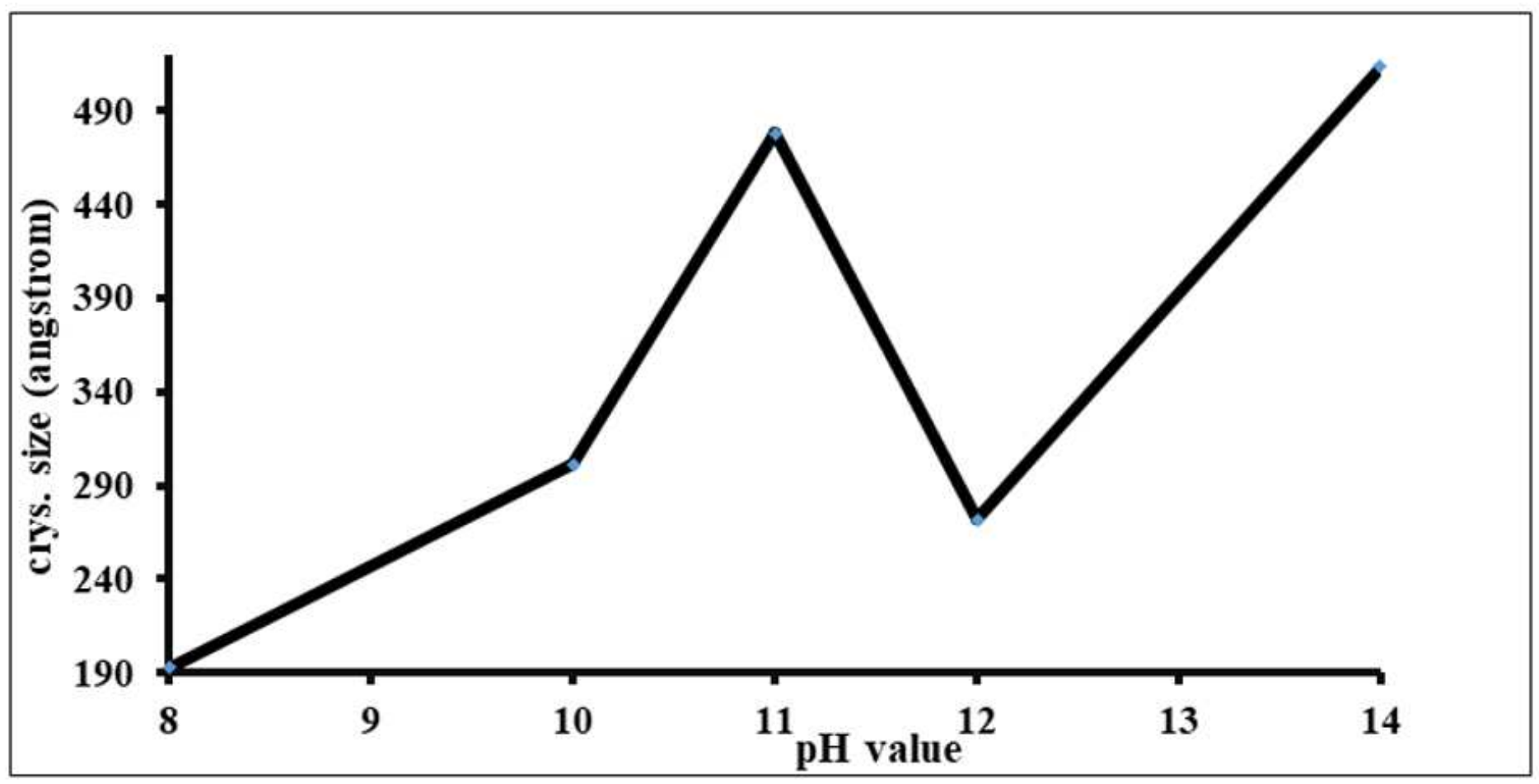

Figure 5

Diagram of the crystallites diameter of the synthesized powders at $750^{\circ} \mathrm{C}$ for $2 \mathrm{~h}$ from zinc doped cobalt ferrites $(0.4$ mole $\mathrm{Zn})$ prepared at different $\mathrm{pH}$ condition 

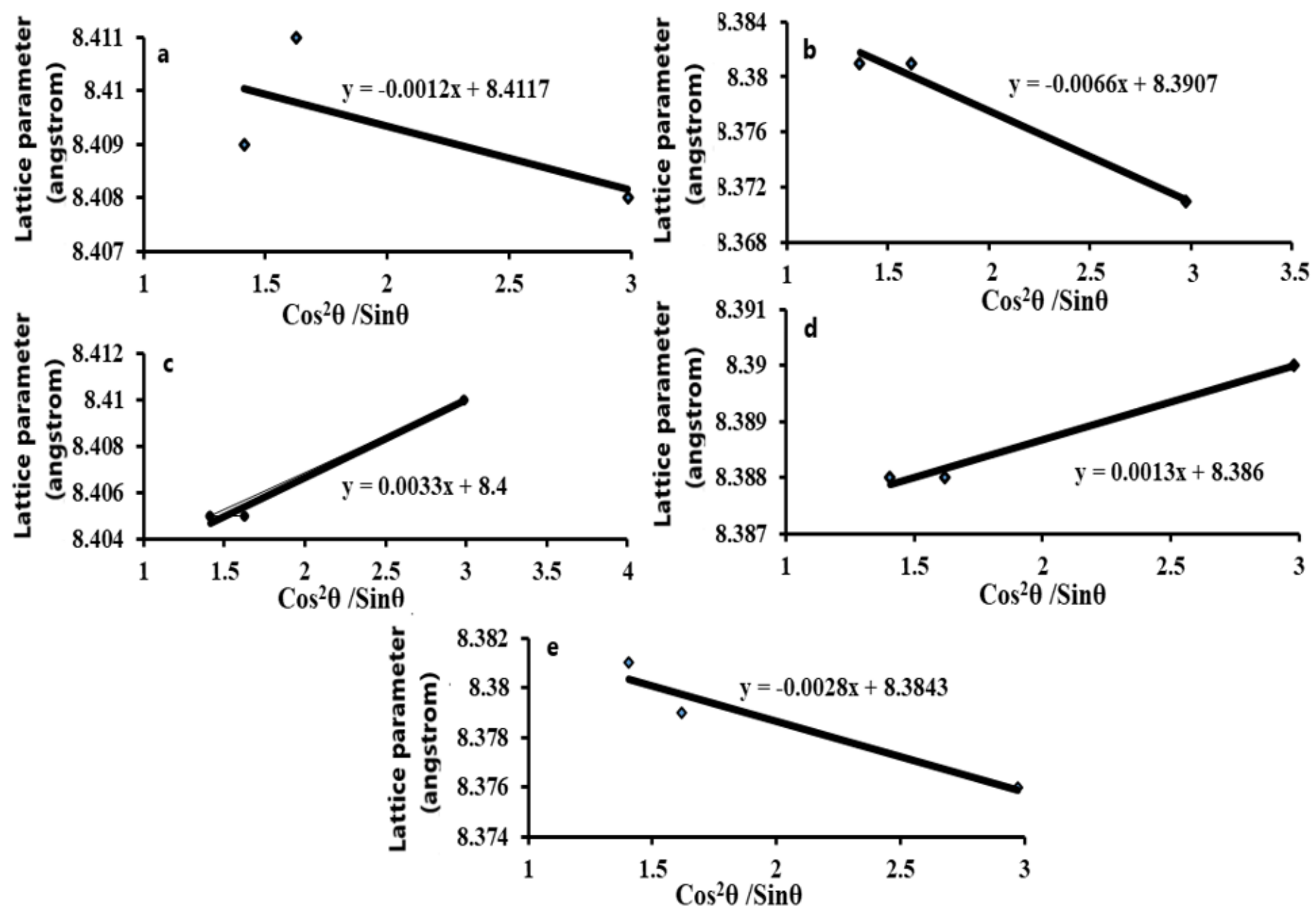

Figure 6

Diagram of extrapolation functions for samples synthesized at $750{ }^{\circ} \mathrm{C}$ for $2 \mathrm{~h}$; (a) Z4P8, (b) Z4P10, (c) Z4P11, (d) Z4P12, and (e) Z4P14 


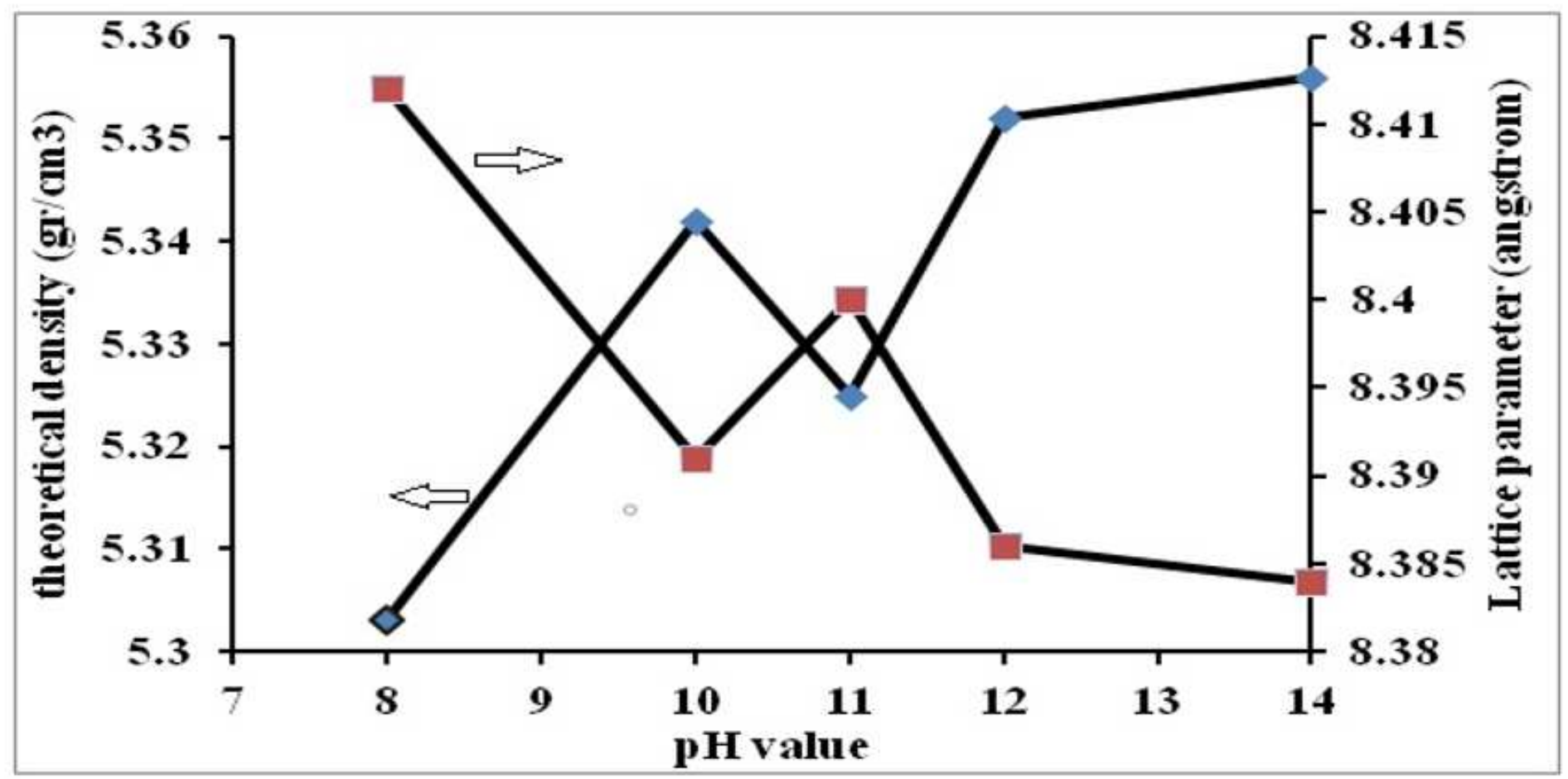

Figure 7

$\mathrm{X}$-ray density graph and lattice parameter of synthesized zinc doped cobalt ferrites $(0.4$ mole $\mathrm{Zn})$ at 750 ${ }^{\circ} \mathrm{C}$ for $2 \mathrm{~h}$ at different $\mathrm{pHs}$ 

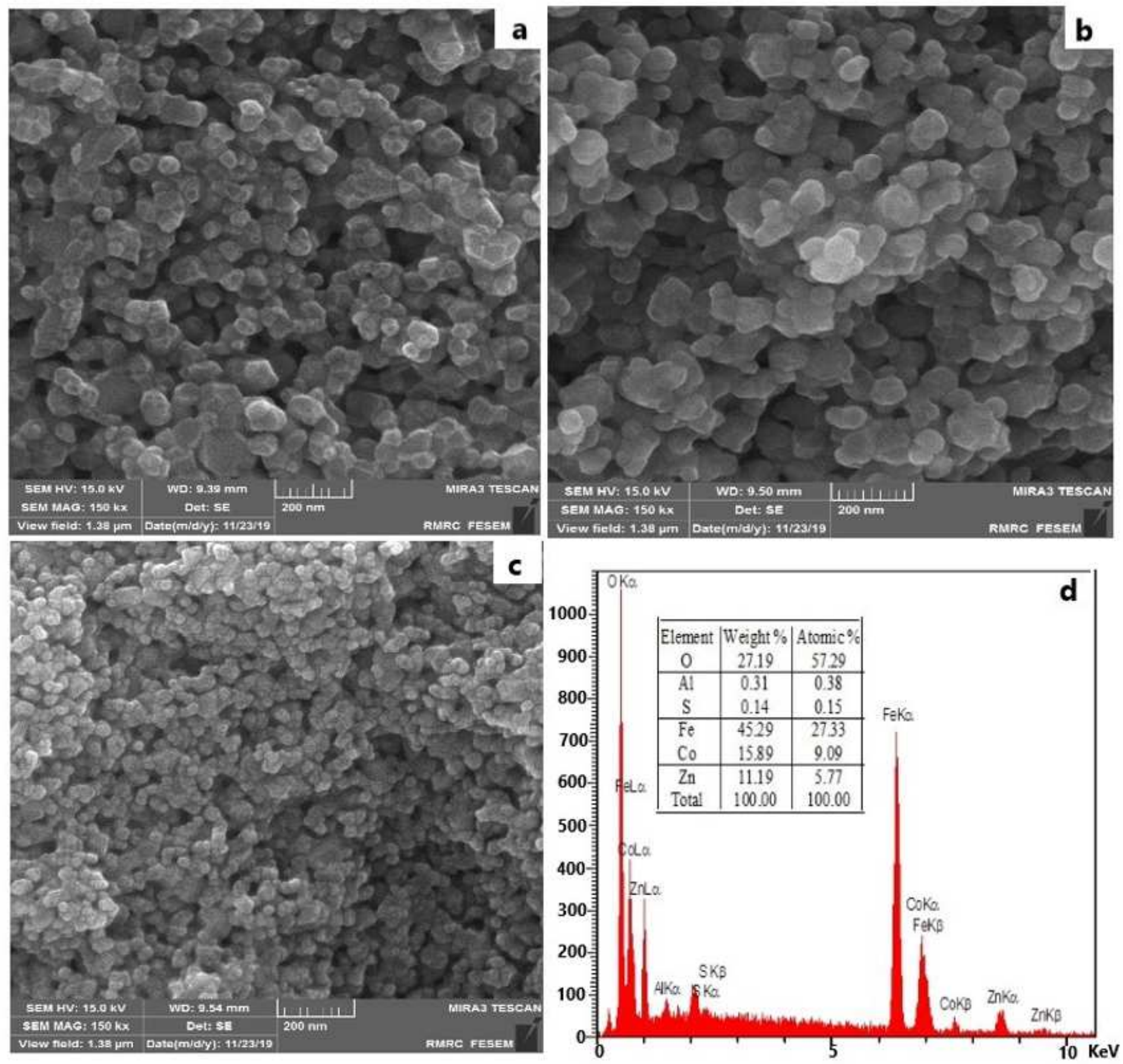

Figure 8

FESEM and EDS analysis of synthesized powders at $750^{\circ} \mathrm{C}$ for $2 \mathrm{~h}$; (a) Z4P8, (b) Z4P11, (c) Z4P14, (d) EDS of Z4P11 specimen 


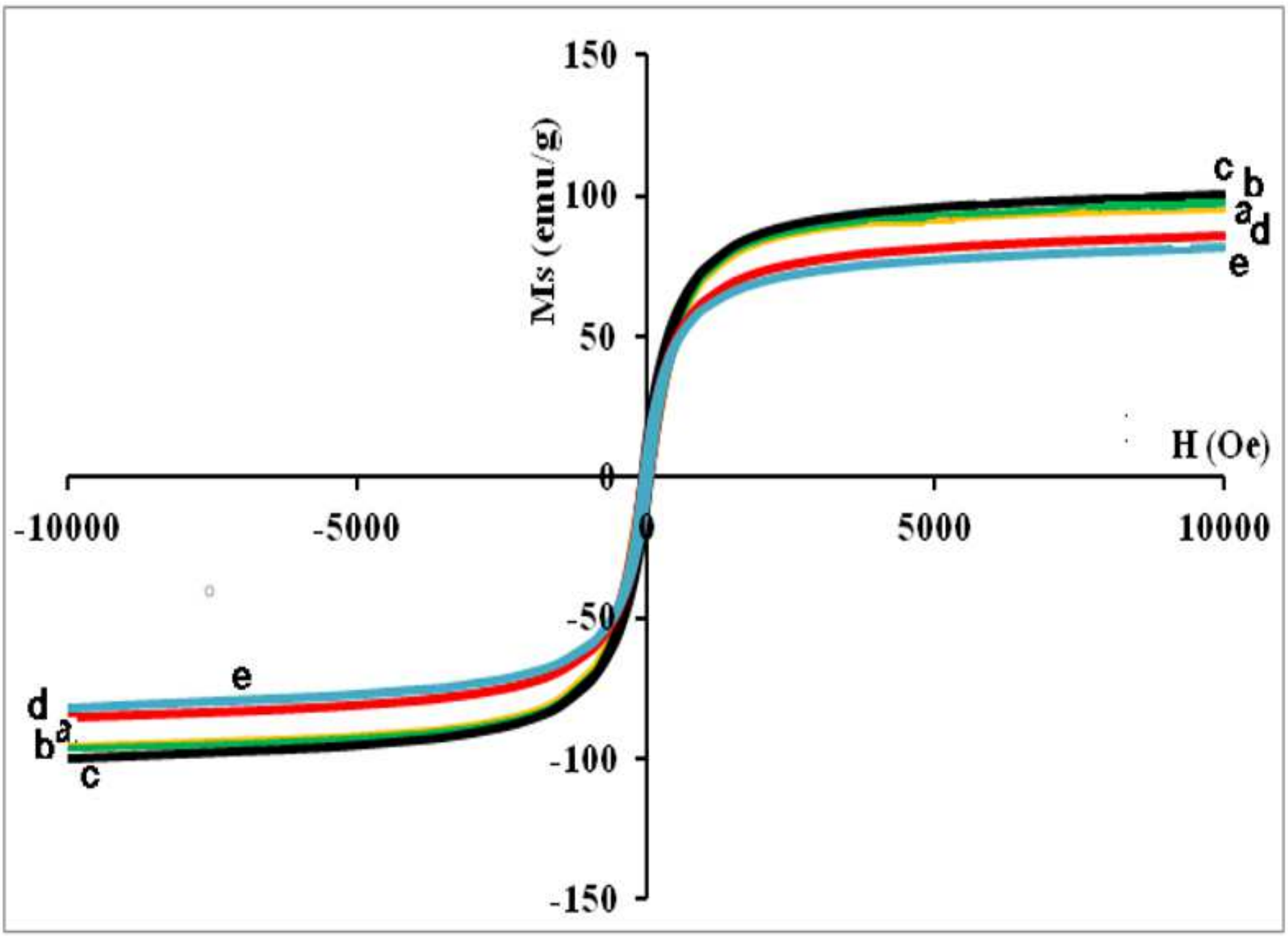

Figure 9

VSM diagram of zinc doped cobalt ferrite (0.4 mole $\mathrm{Zn})$ samples prepared at different pHs and synthesized at $750{ }^{\circ} \mathrm{C}$ for $2 \mathrm{~h}$; (a) $\mathrm{pH}=8$, (b) $\mathrm{pH}=10$, (c) $\mathrm{pH}=11$, (d) $\mathrm{pH}=12$, and (e) $\mathrm{pH}=14$ 


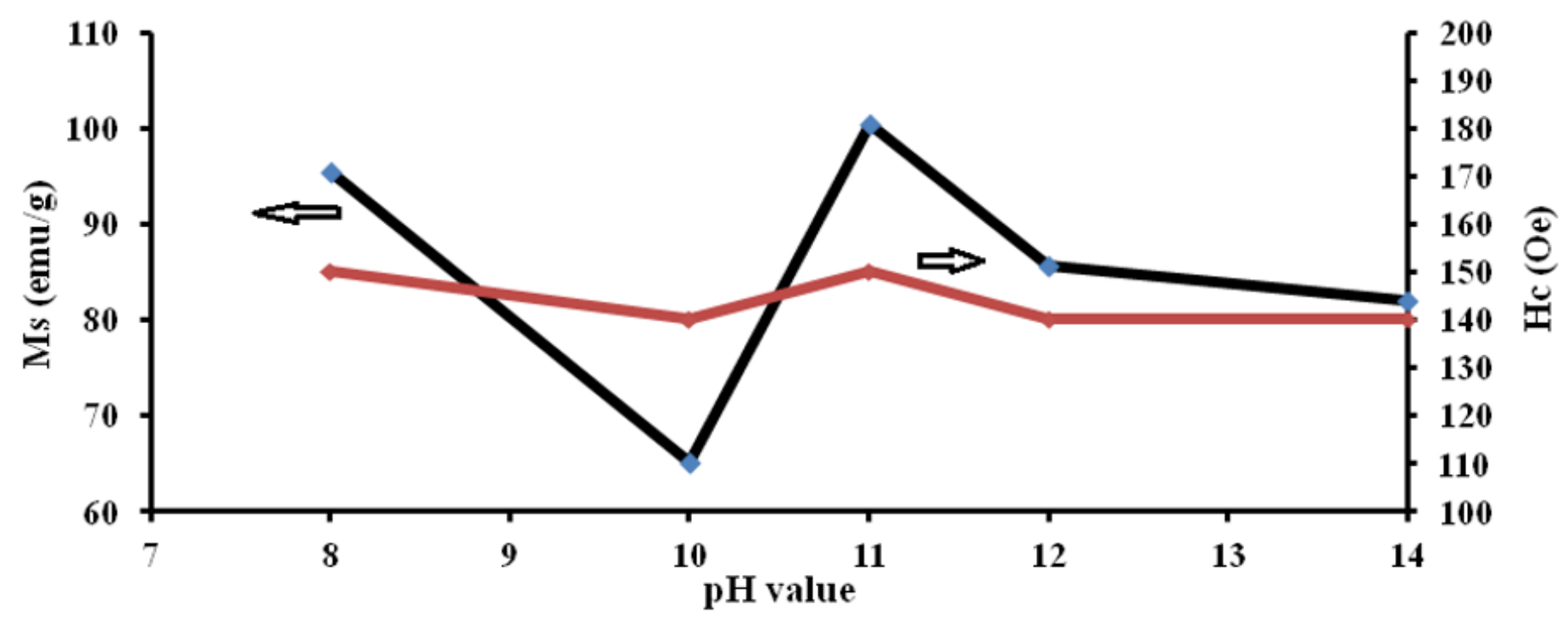

Figure 10

Saturation magnetization and coercive force of $\mathrm{Co} 0.6 \mathrm{Zn} 0.4 \mathrm{Fe} 2 \mathrm{O} 4$ samples prepared at different $\mathrm{pHs}$ and synthesized at $750^{\circ} \mathrm{C}$ for $2 \mathrm{~h}$

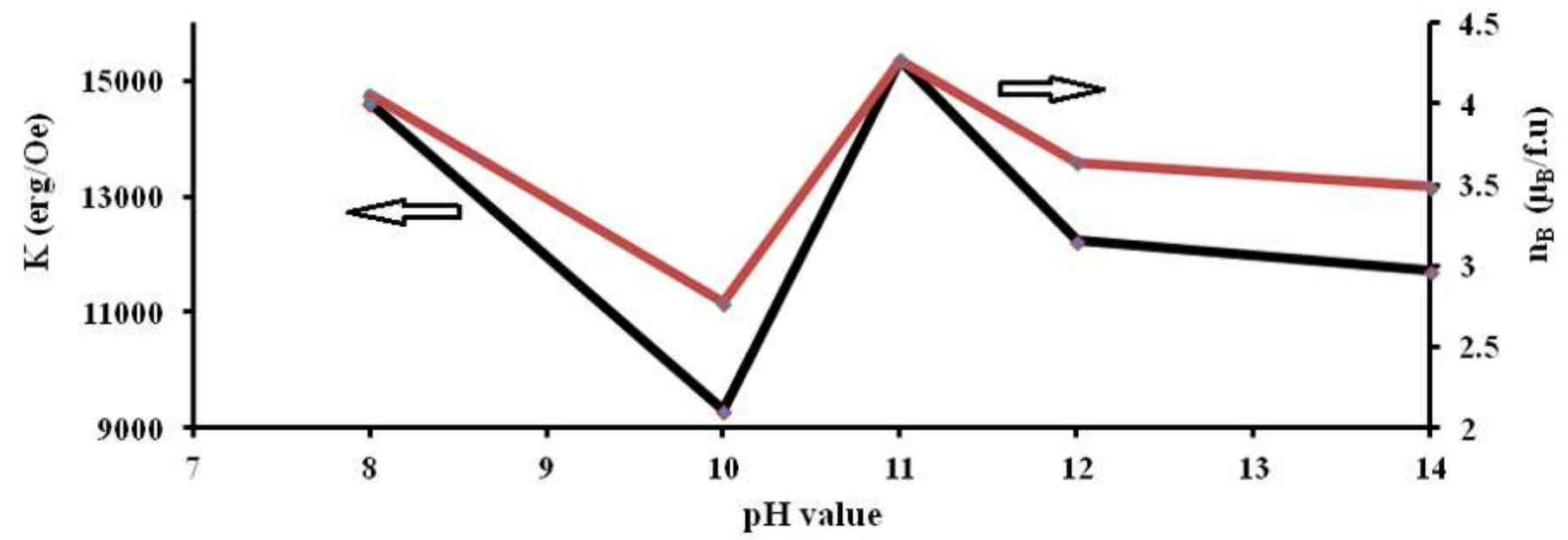

Figure 11

Anisotropic constant and Bohr magneton of $\mathrm{Co} 0.6 \mathrm{Zn} 0.4 \mathrm{Fe} 2 \mathrm{O} 4$ samples prepared at different $\mathrm{pHs}$ and synthesized at $750^{\circ} \mathrm{C}$ for $2 \mathrm{~h}$ 